April 13, 2016

\title{
Cash Holdings and CEO Turnover
}

\author{
Vincent J. Intintoli \\ College of Business \\ Clemson University \\ Clemson, SC 29634 \\ vintint@clemson.edu \\ (864) 656-2263
}

\author{
Kathleen M. Kahle* \\ Eller College of Management \\ The University of Arizona \\ Tucson, AZ 85721 \\ kkahle@eller.arizona.edu \\ (520) 621-7489
}

\begin{abstract}
:
CEO characteristics, such as the level of risk aversion, are known to affect corporate financial policies, and therefore are likely to impact corporate liquidity decisions. We examine changes in cash holdings around CEO turnover events, a period in which discrete changes in managerial preferences and abilities are likely to have the most dramatic effect on cash holdings. Our results suggest that cash holdings increase significantly following forced departures. The increase is persistent over the successor's tenure and is robust to controls for the standard firm-level determinants of cash holdings and corporate governance characteristics. We find that higher cash holding arise mainly through the management of net working capital, as opposed to asset sales or reductions in investment. This suggests that the changes are optimal for shareholders rather than an indication of serious agency problems. This conclusion is supported further by our finding that the marginal value of cash does not decrease following the turnover.
\end{abstract}

*We are grateful for the useful discussions and helpful comments from Tom Bates and Jean Helwege. We would also like to thank Matthew Serfling, Andrew Zhang, H. Zafer Yuksel, Jason Greene, Jamie John McNutt, and seminar participants from Southern Illinois University Carbondale for helpful comments. Naoko Fox, Amine Khayati, and Ryan Stroup provided excellent research assistance. 
A major concern over the last several decades, articulated by Jensen (1986), has been that managerial risk-aversion may lead to excessively high cash buffers that allow entrenched managers to pursue their own investment policies at the expense of shareholders. Entrenched managers may fail to take on good projects because doing so will eat into the buffer or they may hoard cash and later use it for projects, such as acquisitions, that are value destroying. Consistent with Jensen's views, Bertrand and Schoar (2003) find that manager fixed effects increase the explanatory power of a model of corporate cash holdings. Specifically, their results suggest that shareholder value could be enhanced on average if cash holdings were to decrease. This is particularly troublesome in light of the results in Bates, Kahle and Stulz (2009) that cash holdings have been trending up in recent decades.

The impact of manager preferences on firm policies is particularly difficult to identify, let alone quantify precisely enough to determine if cash holdings are optimally chosen. Cash holdings may be low because the firm has been unprofitable and using up liquidity or holdings may be high in anticipation of undertaking a particularly profitable new project. Furthermore, these are factors that are likely to have an effect on the firm's liquidity for several years. Consequently, researchers such as Fee, Hadlock and Pierce (2013), question the validity of the fixed effects approach.

We attack the econometric problems related to cash holdings and CEOs by examining changes in cash around CEO turnover events. These are periods in which discrete changes in managerial preferences and abilities are likely to have the most dramatic effect on corporate policies (e.g., Weisbach, 1995). If risk aversion is a major agency problem before the turnover that leads to abnormally high, inefficient cash holdings, the board should hire a successor whose preferences are less detrimental to the growth of the firm. If cash holdings are low before the turnover event because the firm was heading towards distress, the board ought to find a successor 
who can turn around the firm and build up cash reserves towards the optimal amount. This will be particularly true in the case of forced turnovers where the board is focused on making improvements that help maximize shareholder value. If cash holdings do not change from before to after the turnover event, we conclude that any negative impacts on shareholder wealth arising from cash-related agency problems are too small to affect the board's choice of a successor.

In the case of forced turnover, the new CEO is often an outsider, since potential insider candidates may be too similar to the underperforming predecessor. While potential outsider successors may be the most desirable candidates, conditions associated with the forced turnover may limit the pool of talent that a board chooses from when replacing a CEO. Parrino (1997) argues that the costs associated with replacing a CEO are higher when the successor lacks the necessary human capital to manage the firm's assets and is therefore more susceptible to error and missed opportunities. Naveen (2006) finds support of this view. Thus, we expect that a CEO successor who has little firm-specific experience will be cautious towards his new position and may reduce the risk of a misstep by increasing cash holdings. We expect this effect to be most pronounced following forced turnovers and for firms that hire successors from outside the industry. Because precautionary demand is meant to offset expected losses from distress, this restrained strategy should be in the best interest of shareholders. Thus, we would not view observed higher cash holdings as an indication of managerial preferences that cause an agency problem.

Absent of such considerations, however, we expect forced CEO turnover to lead to more efficient cash holdings policies. If managers are forced out for failure to undertake all positive NPV projects, one would hardly expect the board of directors to appoint a replacement who is even less likely to increase shareholder value. Thus, we expect risk aversion to be less of a problem among the successors in cases of forced departures. Even in the case of voluntary turnover, the 
board is unlikely to choose a successor who is exceptionally risk averse if the previous CEO's preferences toward high cash holdings had a severe negative influence on shareholder value.

Our results suggest that cash holdings increase significantly after a forced CEO turnover. The median cash-to-assets ratio nearly doubles, increasing from $5.17 \%$ during the predecessor period to $9.99 \%$ for the successor period. The increase in cash is persistent over the successor's tenure, and is robust to controls for the standard firm-level determinants of cash holdings and corporate governance characteristics. This result is economically significant, representing an inflation-adjusted \$155.5 million difference in cash holdings for the median firm following a forced CEO turnover. Further, our results indicate that in forced turnover cases the succession of a CEO from outside the industry is associated with significantly greater cash holdings. Since these CEOs are the least likely to be entrenched, this result suggests that higher cash holdings are optimal for the firm.

When we examine event time regressions, using voluntary turnovers as benchmarks, we find that the difference in cash holdings for forced vs. voluntary turnovers is positive and significant in the years following the CEO turnover. For example, in the third year following the turnover, successors following forced turnovers hold nearly 5\% more cash than successors following voluntary departures. CEO successors are more likely to reduce net working capital and save the proceeds as cash than their voluntary turnover counterparts. That is, the increase in cash holdings for forced turnover successors come from the realization of significant efficiencies in net working capital rather than from a reduction in investment in fixed assets.

Lastly, we use the Faulkender and Wang (2006) methodology to estimate the value of cash holdings for firms subject to CEO turnover. Our results suggest that the marginal value of cash changes insignificantly following a CEO turnover, indicating that the additional cash holdings 
attributable to managerial succession are not value destroying. The incremental value of cash is also unchanged following forced departures when the replacement CEO has no industry experience. Given that the marginal value of cash declines with larger cash holdings (Faulkender and Wang, 2006), these results suggest that the increase in cash holdings following managerial turnover is, on average, value enhancing, particularly when a CEO is relatively inexperienced.

Since the observed rise in cash holdings is largely due to increased efficiency in the management of net working capital (as opposed to asset sales or reductions in investment) and the marginal value of cash does not decrease following the turnover, we conclude that the changes in cash holdings are not indicative of the agency problems highlighted in Jensen (1986).

The paper proceeds as follows. Section 1 provides a review of related literature. Section 2 describes our sample selection procedure and summary statistics on the determinants of cash holdings. Section 3 provides multivariate results on cash holdings, measures the value of cash holdings, and examines the determinants of cash savings. Section 4 contains additional robustness checks, while Section 5 concludes.

\section{The Determinants of Corporate Cash Holdings}

The primary benefit of holding cash comes from its use as a precautionary tool to hedge against underinvestment when a firm experiences shortfalls in operating cash flows. In addition, cash holdings reduce the transactions costs that a firm incurs when it must convert a non-cash financial asset into cash for payments. Opler, Pinkowitz, Stulz, and Williamson (1999) show that a company's expected cash holdings are a function of several key characteristics, including size, risk, and growth potential. The basic premise underlying their model is that smaller, riskier companies with promising growth opportunities choose to hold more cash than large, stable, and 
relatively mature companies with reliable access to outside capital. More recently, Bates, Kahle, and Stulz (2009) show that firm cash holdings have increased over time in a manner that is consistent with a higher precautionary demand for cash.

The disadvantage of high cash holdings, according to Jensen (1986), is the potential agency cost. Specifically, in the absence of valuable investment opportunities, corporate managers may waste excess cash reserves by making bad acquisitions or pursuing growth at the expense of shareholder value. Several studies examine the effect of corporate governance and agency costs on cash holdings. For example, Harford (1999), Dittmar, Mahrt-Smith, and Servaes (2003), Pinkowitz, Stulz, and Williamson (2006), Dittmar and Mahrt-Smith (2007), and Harford, Mansi, and Maxwell (2008) generally conclude that companies with large cash reserves and weak corporate governance systems tend to invest cash poorly, and that cash holdings are less valuable in these companies.

A growing literature on the influence of CEO style and ability on corporate policies suggests that they can affect cash reserves (e.g., Custodio and Metzger, 2013; Adams, Almeida, and Ferreira, 2005; Graham, Harvey, and Puri, 2013; Cronqvist, Makhija, and Yonker, 2012; and Malmendier, Tate, and Yang, 2009). Bertrand and Schoar (2003) examine leverage and liquidity decisions and find significant CEO fixed effects. These results suggest that the degree of financial slack in a firm is driven, in part, by the preferences or abilities of managers. This evidence is largely consistent with the negative view expressed by Jensen (1986). However, Fee, Hadlock, and Pierce (2013) question these findings in part due to endogeneity concerns. Evidence in Schoar (2007) also indicates that a CEO’s past business experience can have an impact on future corporate policies and performance. 
In related work, Peters and Wagner (2014) find a positive relation between the probability of forced turnover and CEO compensation. In addition to causing managers to demand higher compensation, turnover risk could cause managers to increase cash holdings to protect themselves.

Dittmar and Duchin (2016) examine how CEOs' prior work experiences affect cash holdings. Using a sample of exogenous CEO turnovers (turnover due to death or illness, planned retirements, or scheduled successions) they find that firms run by CEOs who faced financial difficulties during past employment at other firms hold more cash. They conclude that past professional experience shapes the way managers make future financial decisions. However, even in instances of exogenous turnover, the board is likely to hire a CEO who will implement the board's desired policies, so it is unclear whether any changes are due to the CEO's preferences or the board intentionally hiring a CEO with those preferences.

\section{Sample Selection and Summary Statistics}

We construct our sample of turnover events from Execucomp. We exclude financial firms (SIC codes 6000-6999) and utilities (SIC codes 4900-4999) and restrict our sample to only include Execucomp firm-years that identify the beginning and end date of the current CEO. We next search the Wall Street Journal to verify the exact date of each turnover event and to obtain predecessor and successor characteristics. Due to the importance of correctly identifying forced and voluntary turnovers for our analysis, we drop all observations where we cannot find public notice of the CEO change. Consistent with previous work (Parrino, 1997), we define forced turnovers as CEO departures (1) explicitly identified in the Wall Street Journal as being forced, or (2) when the incumbent CEO is less than 60 years old and the reason for departure is not specified as being due 
to poor health, death, or the acceptance of a new position within or outside of the firm. Otherwise, we classify the turnover event as voluntary.

Since incoming CEOs cannot instantaneously change corporate policies, we focus our analysis on years $t=-4$ to $t=+4$ relative to the turnover event $(t=0)$ in order to effectively examine cash holdings for both predecessor and successor. Consequently, we limit our turnover sample to those announced from 1992 through 2003. In this way, we examine succession years only through 2007, which ensures that the cash holdings of our sample firms will not be influenced by the credit crisis, which has been tied to a period of cash hoarding by firms (e.g., see Ganor, 2011; and Kahle and Stulz, 2013). We also limit our sample to only include firms where the predecessor (successor) has tenure of at least two years (one year), since it is unlikely that the chief executive will be able to influence firm operations in a material way if his tenure with the firm is limited. Moreover, we exclude the last year (first year) of tenure for the successor (predecessor) when tenure is between two and four years from our analysis since firm policy may be influenced by both the departing incumbent and incoming chief executive during these periods. For this same reason, we exclude the year of the turnover (except when otherwise noted) since it represents a transition period for executives and it is unclear whether predecessor or successor policy is implemented at this time. The sample is further structured so that only turnovers with both successor and predecessor characteristics are included.

All observations with turnovers that pertain directly to a merger or acquisition are excluded from the sample. We also eliminate any instances where the successor held or currently holds the Chairman of the Board position in the pre-turnover period, since the successor presumably will already have influence over firm operations prior to his appointment to the top post. Lastly, we exclude any firms that delist within three years after the turnover since CEOs for these firms will 
most certainly be limited in actively managing firm cash reserves. Data for the accounting variables of interest are from the WRDS merged CRSP/Compustat files for the period 1988 to 2007 and we limit our firm-year observations to only include years that have positive assets and sales. Our post restriction sample yields over 4,300 firm-year observations for 550 turnovers events. Complete variable definitions are provided in the Appendix.

\subsection{Summary Statistics}

Table 1 provides summary statistics of the different variables employed in this study for both predecessor and successor CEOs. Panel A examines cash and the accounting determinants of cash used in previous studies. Panel B examines firm specific ownership and corporate governance variables, as well as executive-specific characteristics of the predecessor and successor. All firmspecific and executive-specific variables are first averaged across executive years.

Definitions for variables shown in Table 1 are provided in the appendix. Median cash/assets increases from $4.5 \%$ to $5.3 \%$ following the turnover (p-value $=0.045) .{ }^{1}$ Inflationadjusted book assets is also higher during the successor tenure than the predecessor tenure; the medians are significantly higher. Mean market-to-book ratios fall, although the medians are not different. Both mean and median cash flow from assets are significantly lower for the successor, while median cash flow volatility increases. Net working capital as a percent of assets falls significantly after turnover, as do capital expenditures, but R\&D as a percent of sales and acquisitions as a percent of assets do not differ significantly between the predecessor and

\footnotetext{
${ }^{1}$ At first glance, these results may seem to counter that of Cunha and Ribas (2012), who do not find any CEO effect on cash holdings. However, their finding is likely due to model specification, in that the effect of the turnover is identified only through an examination of year of the CEO departure (i.e., $\mathrm{t}=0$ in our sample).
} 
successor. Write-downs as a percentage of assets increase from predecessor and successor tenure periods. ${ }^{2}$ Finally, there is no significant change in the percentage of firms that pay dividends. ${ }^{3}$

Panel B shows that successor CEOs are both younger and less likely to be a member of the founding family than the predecessor CEOs. Successors are also less likely to hold the title of both CEO and Chairman of the Board. While there is no significant difference in board size between predecessors and successors, the both the mean (median) percentage of outside directors increases significantly following turnover, from $74.75 \%(77.34 \%)$ to $78.31 \%(80.02 \%)$. Both mean and median blockholder ownership also increases significantly from the pre- $(28.31 \%, 24.24 \%)$ to post-turnover (31.66\%, 28.95\%) periods.

Table II further divides our sample into forced (Panel A) and voluntary (Panel B) turnovers. Both mean and median cash/assets increase significantly following forced turnover; mean cash increases from $9.6 \%$ to $12.9 \%$, while median cash nearly doubles, increasing from $5.2 \%$ to $10.0 \%$. This difference represents a median increase in raw cash holdings from predecessor to successor period of over $\$ 155$ million. ${ }^{4}$ This result suggests that high cash holdings benefit shareholders at the time of turnover, which is likely due to the higher expected costs of distress around these times.

Consistent with the prediction that distress costs are higher, we find that, similar to the entire sample of turnovers, firms experience a decline in cash flow around forced turnovers while cash flow volatility increases. Net working capital and capital expenditures (as a percent of assets) decrease, while $\mathrm{R} \& \mathrm{D} /$ sales is unchanged. Write-downs increase following forced turnovers, which

\footnotetext{
${ }^{2}$ We define write-downs as special items (spi) scaled by assets. Since we are only concerned with write-downs and not write-ups (i.e., when the firm increases the value of assets) we set our write-down variable to zero when data item $s p i$ is missing or positive. We find materially similar results if we use data item $w d p$ scaled by assets.

${ }^{3}$ In untabulated results we also examine the ratio of total dividends to assets and find results similar to using the dividend dummy. Therefore, when controlling for the type of turnover it does not appear that successors change dividend policies in order to influence cash holdings.

${ }^{4}$ Raw inflation-adjusted median cash holdings (reported as 2007 values) for predecessor (successor) tenure periods are \$200.08 million (\$355.55 million), respectively.
} 
is also similar to the results for the entire sample. Acquisitions as a percentage of assets decrease following forced turnovers. These changes in fundamentals are consistent with an increased risk of distress and thus a higher need for a liquidity buffer. However, they may also be indicative of wasteful policies that continue even with the new successors.

Differences between executive specific and governance characteristics remain largely similar for the entire sample and forced turnover sample. Successors are more likely to be younger and less likely to be a founding family member or hold the Chairman post. However, the results on ownership differ for forced turnovers compared to the entire sample. Unlike Table I, there is no significant change in block ownership following forced turnovers.

Turning to the voluntary turnover sample, shown in Panel B, we find that there is no change in cash/assets from predecessor to successor periods. There are also no significant changes in cash flow or cash flow volatility following voluntary turnovers. Net working capital and capital expenditures both decrease, but the magnitude of the decreases are not nearly as large as in the forced turnovers. For voluntary turnovers, median acquisitions/assets actually increase following the turnover. Similar to that of forced turnovers, write-downs increase following the voluntary turnover. The results on the CEO and corporate governance characteristics are similar to those found in Table I for the entire turnover sample. In particular, and in contrast to the forced turnover sample, blockholder ownership increases.

We next examine whether the characteristics of forced predecessors (successors) are different from those of voluntary predecessors (successors). For the sake of brevity, we exclude pvalues and simply indicate statistical differences across these samples using subscripts (a p $<0.01$, $\mathrm{b} p<0.05, \mathrm{c}<<0.10$ ). Shown in Panel A of Table II, we find that predecessor CEOs in forced turnovers 
have significantly higher leverage, are younger, and are less likely to hold the title of CEO and Chairman of the Board than their counterparts in voluntary turnovers.

Successor CEOs following forced turnovers hold more cash than their counterparts from voluntary turnovers (12.9\% vs. 9.5\%, on average). They are also more levered, have lower marketto-book ratios, lower cash flows, higher cash flow volatility, and are less likely to pay dividends than successors in voluntary turnovers. In addition, they have lower net working capital and spend less on acquisitions. In terms of corporate governance characteristics, successors in forced turnovers are less likely to hold the title of CEO and Chairman of the Board and have smaller boards than their counterparts in voluntary turnovers.

We also examine executive tenure with the firm, although we do not report the results in Table II since they are largely consistent with results on CEO age. Not surprisingly, mean and median CEO tenure is longer in the case of voluntary turnover compared to forced turnover. Both mean and median predecessor tenure is also longer than that shown in previous studies, which can be attributed to our data restriction of only including turnovers where the predecessor remains with the firm for at least two years. ${ }^{5}$

Finally, in untabulated results, we examine inside vs. outside successors and outside industry successors. Outside successors are executives who are employed with the firm for at most one year prior to being appointed CEO. We identify outside industry successors by examining the industry of the firm successor's last appointment, where the Fama and French 48 industry portfolios are used to determine industry classification. ${ }^{6}$ However, we find materially similar results when identifying outside industry successors using 2-digit SIC code. If the successor comes from an entity that does not have an available industry class (e.g., foreign firm or government

\footnotetext{
${ }^{5}$ For example see Coles, Daniel, and Naveen (2008).

${ }^{6}$ We would like to thank Kenneth French for providing the industry level identifiers available through his website.
} 
position) or whose main responsibilities were for a subsidiary that is largely unrelated to the stated classification of the parent company (e.g., CEO of Kraft, which previously was a subsidiary of Phillip Morris) we manually compare the characteristics of the previous position held with the industry of the new post to determine outside industry affiliation. We find no significant differences in the ages of inside successor, outside successor, and outside industry successors. Inside successors are more likely to be members of the founding family, however.

\section{Results}

Univariate results in Table I show that cash holdings increase following top managerial changes, while Table II suggests that much of the increase in cash holdings come during the tenure of successors who are appointed following forced CEO departures. In Table III we further examine this increase in cash holdings in a multivariate setting by modeling holdings controlling for the type of turnover, standard determinants of cash holdings, corporate governance, and executivespecific characteristics. All models include both firm and year fixed effects and standard errors are clustered at the firm level.

Consistent with Opler, Pinkowitz, Stulz, and Williamson (1999), Model 1 shows that cash is negatively related to leverage, net working capital, capital expenditures, and dividends. Cash is positively associated with the market-to-book ratio and cash flow volatility. Model 2 introduces indicator variables for forced turnover. After controlling for the other determinants of cash, and consistent with our univariate results in Table II, cash holdings are significantly higher for successors following forced turnovers.

Model 3 results suggest that outsiders are not associated with holding higher levels of cash. However, precautionary motives may lead outside industry successors appointed following forced 
departures to hold higher levels of cash due to the combined effect of their lack of industry-specific knowledge and the nature of the predecessor departure. To test this prediction, in Model 4 we introduce an interaction term between forced turnover successors and outside industry successors (Forced_Succ*Outside_Ind). Coefficients on both the forced turnover successor control and the interaction are positive and significant, indicating that successor CEOs hold more cash than their predecessor CEOs following forced turnovers and that this is even more true for successors from outside the firm's industry. ${ }^{7}$ Less experienced successors may also be more likely to hold higher levels of cash when operating in firms that require significant R\&D expenditures. To test this prediction, in Model 5 we identify positive R\&D spending firms (R\&D Dummy) and interact it with our outside industry successor control. The positive and significant coefficient on this interaction supports our prediction.

Model 6 incorporates executive specific characteristics that may influence cash holdings. CEO age is used to further proxy for risk aversion (Peters and Wagner, 2014; Serfling, 2014) and CEO duality and founding family relation are additional proxies for executive control over firm operations. We use an indicator for age greater than 60 and for founding family relation. The indicator on CEO age is positively related to cash holdings, indicating that older CEOs tend to hold higher levels of cash. ${ }^{8}$ Founding family affiliation is statistically unrelated to cash holdings. Model 7 further controls for internal and external governance mechanisms (board size, independence, and block ownership) and although no single variable is significantly related to cash holdings, the forced turnover successor variable is robust to including these controls. The board

\footnotetext{
${ }^{7}$ We also examine outside appointments irrespective of successor industry affiliation and find that, overall, outside appointments are unrelated to the level of cash holdings.

${ }^{8}$ In untabulated results, we further analyze CEO age by separating our age dummy into predecessor and successor groups and find that significance only comes from predecessor age. This is not surprising, since most successors are well under 60 years old (median $=55$ years) at the time of their appointment.
} 
may give some successors free rein over firm operations, thus reducing the precautionary motive to hold cash. To proxy for such instances, we identify successors that are appointed to both the CEO and Chairman positions following a forced departure (Forced_Succ*CEO_Chair). The negative coefficient on this interaction provides some support for this prediction.

Overall, these results indicate that higher cash is associated with increased precautionary demands for cash. The higher demand seems likely to reflect the need to protect against financial distress in the early years of a new CEO's tenure. This view draws particular support from our findings on outsiders in cases of forced turnover and in regards to R\&D.

\subsection{Time series changes in cash}

We next compare firm level actual and predicted levels of cash, following the procedure used in Bates, Kahle, and Stulz (2009). First, we estimate a cash holdings model from 1980-1989, the period prior to our turnover sample period, using Fama-MacBeth regressions for all nonfinancial, non-utility firms on Compustat. The coefficients in our model are the average coefficients from annual cross-sectional regressions estimated over this period. Then we compute the difference between actual and predicted cash holdings in our turnover sample.

Table IV reports the predicted cash ratios and the deviations from actual for our whole sample of turnover and for the sample of forced turnovers. For the entire turnover sample, actual cash holdings are less than predicted in all years surrounding the turnover event. When we divide the sample into forced vs. voluntary turnovers, however, we find that for forced turnovers actual cash is less than predicted in predecessor tenure years -3 to -1 relative to the turnover, but cash is greater than predicted by successor tenure years 3 and 4 relative to the turnover. For voluntary turnovers, cash is less than predicted both before and after the turnover for all predecessor and 
successor years. These results lend further support to the idea that successors hold higher levels of cash following forced turnovers.

We next estimate event time regressions, using voluntary turnovers as benchmarks, and compare the evolution of cash holdings around forced and voluntary turnovers using the following model:

$$
Y_{i t}=\alpha+\sum_{\eta=-N}^{+N} \beta_{\eta}^{F} F_{i \eta}+\sum_{\eta=-N}^{+N} \beta_{\eta}^{V} V_{i \eta}+\beta^{\prime} X_{i t}+\varepsilon_{i t}
$$

The dependent variable, $\mathrm{Y}_{i t}$ is cash holdings and $\mathrm{X}_{i t}$ represents a vector of control variables, where $i$ and $t$ represent firm and year. The notation $\eta$ represents the year relative to the CEO turnover and spans from $-N$ to $+N$, where $-N$ begins three years prior to the turnover and $+N$ ends three years after the turnover. ${ }^{9} F_{i \eta}$ and $V_{i \eta}$ are indicator variables set equal to 1 for forced $\left(F_{i \eta}\right)$ and voluntary $\left(V_{i \eta}\right)$ turnover firms $i$ in year $\eta$. The coefficients on these variables $\left(\beta_{\eta}^{F}\right.$ and $\beta_{\eta}^{V}$ ) represent the annual specific cash holdings for firms where the CEO is forced out or departs voluntarily. The difference in these coefficients $\left(\beta_{\eta}^{F}-\beta_{\eta}^{V}\right)$ represent the percentage point difference in cash holdings for each year $\eta$ for firms surrounding forced turnovers relative to those facing voluntary turnovers, after controlling for other determinants of cash holdings $\left(\mathrm{X}_{i t}\right)$. For example, a difference of .02 for $\beta_{1}^{F}-\beta_{1}^{V}$ means that in the year after a CEO departure, successors in forced turnover firms hold 2\% more cash than voluntary turnover firm successors.

Table V provides the results of the event time regressions. Model 1 includes controls for year and firm fixed effects. In this model, the percentage difference in cash holdings in forced vs. voluntary turnovers is negative and significant in years -3 to -1 relative to the turnover, which

\footnotetext{
${ }^{9}$ In unreported analysis we use different event windows surrounding the turnover and find similar results.
} 
indicates that predecessors who are soon forced out tend to hold less cash than their voluntary turnover counterparts. The difference is insignificant in years 0 and +1 relative to the turnover, which is not surprising since the year of the turnover $(\mathrm{t}=0)$ will include periods of both predecessor and successor tenure and it may take time for a successor to implement general policies that will influence cash holdings in a material way.

Interestingly, the difference in cash holdings for forced vs. voluntary successors is positive and significant in years +2 and +3 . Specifically, the coefficient of .0493 for year three indicates that successors following forced turnovers hold nearly 5\% more cash than successors following voluntary turnovers in the third year following the turnover. Given that the inflation-adjusted annual cash holdings for our sample averages \$659 million, this figure represents \$32.5 million more cash held by successors who follow forced turnovers when compared to voluntary turnover successor cash holdings. Overall these results indicate CEOs who were forced out held less cash than the CEOs who left their jobs voluntarily. Consistent with the precautionary hypothesis, successors in forced turnovers increase cash significantly following the turnover, relative to successors in voluntary turnovers.

Model 2 of Table V adds controls for the usual determinants of cash used in Table IV, while Model 3 also adds controls for the corporate governance variables. Once these other determinants of cash are controlled for, the differences in cash holdings prior to the turnover are no longer significant. Cash holdings are still significantly higher following forced turnovers relative to voluntary turnovers, however.

Figure 1 represents the results from Panel A of Table V graphically. The percentage difference in cash holdings between CEOs in forced turnovers relative to voluntary turnovers is 
slightly negative in the years leading up to the turnover event. The difference becomes positive in the second year after the turnover and continues to increase in the third year of tenure.

Panel B of Table V aggregates the annual cash holdings into predecessor $\left(\beta_{-}^{F}-\beta_{-}^{V}\right)$ and successor $\left(\beta_{+}^{F}-\beta_{+}^{V}\right)$ periods using the following equation:

$$
Y_{i t}=\beta_{-}^{F} F_{-}+\beta_{+}^{F} F_{+}+\beta_{-}^{V} V_{-}+\beta_{+}^{V} V_{+}+\beta^{\prime} X_{i t}+\varepsilon_{i t}
$$

Similar to Models 2 and 3 of Panel A, aggregate differences in cash holdings for predecessors who are forced from their post are statistically no different than for predecessors who eventually leave voluntarily. However, aggregate successor periods again show higher cash holdings for forced turnover successors. The difference-in-differences test, $\left(\beta_{+}^{F}-\beta_{+}^{V}\right)-\left(\beta_{-}^{F}-\beta_{-}^{V}\right)$ also shows that forced turnover successors hold more cash than voluntary turnover successors.

\subsection{Determinants of cash savings}

We next turn to an examination of the sources of the observed higher cash holdings following forced turnovers. If we find that cash holdings arise from lower leverage (reduced dividends, higher equity issuance or lower share repurchases), lower investment or from divesting profitable businesses, we will infer that the changes reflect risk aversion. We start by examining the proceeds from the sale of common and preferred stock less the repurchase of common and preferred and cash dividends (Net Issue), the issuance of long-term debt minus long-term debt reduction (Net Debt), and the sum of proceeds from the sale of property, plant, and equipment net of capital expenditures (Net Sale PP\&E). If cash holdings have increased at the expense of future investment, then agency problems may drive the results observed thus far. 
In addition, we also examine changes cash flows and the various components of net working capital since they can also provide sources of cash holdings. ${ }^{10}$ Firms can tie up significant amounts of cash in inventory, increasing current assets. If higher cash holdings arise from reduced inventories the overall impact may be greater efficiency rather than agency problems related to risk aversion. Likewise, high receivables levels may reduce cash holdings and changes in receivables after a forced turnover may also be related to efficiency gains.

Univariate statistics for the determinants of cash savings are provided in Table VI. Panel A shows that mean and median Net Debt issuance fall significantly following forced turnovers, which is in line with the idea that the ability (or willingness) to borrow additional long-term funds may be impaired for some firms following forced turnovers. The net sale of PP\&E increases, providing a source of cash for CEOs following forced turnovers, while cash flows decrease from the predecessor to successor tenure periods. Examining the components of net working capital, we find that successors following forced turnovers decrease current assets as a whole. These reductions come from a significant decrease in both mean and median levels of receivables and inventory. Alternatively, median levels of short term debt fall following forced turnovers.

Panel B shows that net issues and cash flow both decrease during successor tenure following voluntary turnover. In addition, current assets, receivables, inventory, and payables fall. Overall, our univariate results suggest that sources of cash savings can be seen in firms following both forced and voluntary turnover. We turn to multivariate analysis to disentangle the relation between CEO type and supply of cash holdings.

\footnotetext{
${ }^{10}$ In unreported analysis we examine the sale of investments (siv) and other sources of funds (fsrco) and find that they are unrelated to changes in cash holdings over predecessor and successor tenures. However, our main results are robust to including these factors.
} 
We measure cash savings using a model similar to McLean (2011), who examines how the propensity to save share issuance proceeds as cash has evolved over time.

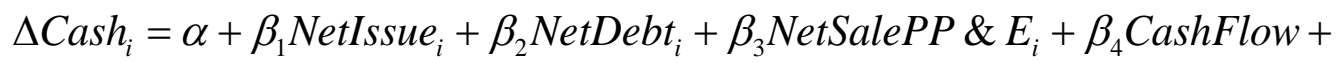

$$
\begin{aligned}
& \beta_{5} \operatorname{Ln}(\text { Assets })_{i}+\varepsilon_{i}
\end{aligned}
$$

where $\Delta$ Cash $_{i}$ is the change in cash from t-1 to t; NetIssue is proceeds from the sale of common and preferred stock minus the purchase of common and preferred less cash dividends; NetDebti is proceeds from long-term debt issuance minus long-term debt reductions; NetSalePP\&Ei is the sale of property, plant, and equipment less CAPEX; CashFlowi is net income plus depreciation and amortization; and $\operatorname{Ln}$ (Assets) $i$ is the book value of assets. All variables except assets are scaled by the lagged book value of assets. The coefficients from Equation (3) can be interpreted as cents saved per dollar of cash proceeds. We estimate a similar equation to determine the sources of the cash increase observed following forced turnovers. However, we also include the change in net working capital (excluding cash) as a potential source of cash. In addition, we include a dummy for forced turnover successors and interactions between this dummy and the sources of cash.

The results of the sources of cash regressions are in Table VII. Models 1 and 2 examine the determinants of cash irrespective of the controlling CEO. The change in cash is significantly positively related to proceeds from net equity and issuance, net sale of PP\&E, and cash flow. It is significantly negatively related to the change in net working capital. Model 3 incorporates our forced turnover successor indicator, which is positive and significant, indicating that the change in cash is greater following forced turnovers. The interactions between this dummy and net working capital is negative and significant, shown in Model 4. This finding, combined with the results in Table II that net working capital decreases significantly (from 8.6\% to 3.4\% of assets) following forced turnovers, indicates that successors in forced turnovers are more likely to reduce net working capital and save the proceeds as cash than their voluntary turnover counterparts. The 
interaction between forced turnover successors and proceeds from net long-term debt issuance is positive and significant. Although successors following forced turnovers are decreasing long-term debt levels on average (shown in Table VII), the positive coefficient on this interaction indicates that successors who chose to issue debt tend to keep more of the proceeds as cash.

In Table VIII, we again examine sources of cash regressions, but further break down changes in net working capital into changes in the different components of net working capital, where Panel A includes components of current assets (less cash) and Panel B examines components of current liabilities. Investigating net working capital in this manner enables us to determine the specific sources of cash used by successors following forced turnovers. The components examined include: accounts receivable, inventory, other current assets, accounts payable, short-term debt, and other current liabilities.

Panel A reports negative and significant interactions between forced turnover successors and changes in inventory. Recall from Table VI that inventory (16.52\% to $12.71 \%$ of assets) significantly decreases in the post-turnover successor period. These results indicate that successors in forced turnovers are more likely to reduce net working capital and save the proceeds as cash than their voluntary turnover counterparts.

Results from Panel B show, similar to our findings on long-term debt issuances, the interaction on the change in short-term debt and forced successors is positive and significant, where Table VI shows that short-term debt falls in the successor tenure period following forced turnovers. We interpret these results as further support for the idea that successors who chose to increase short-term financing following forced turnovers tend to keep more of the proceeds as cash. Taken as a whole, the results from Tables VI-VIII indicate that the increase in cash holdings for forced turnover successors are obtained from cash savings from changes in net working capital. 


\subsection{Measuring the value of cash}

If the excess cash holdings observed following forced turnovers are value-decreasing then we would expect a negative marginal value of cash holdings for these firms. Alternatively, if the excess cash holdings are appropriate given CEO risk preference and experience, then we expect that the marginal value of excess holdings will be unrelated to our proxies for successor risk preference and inexperience. A number of recent papers correlate agency costs of cash with the value of corporate cash holdings. ${ }^{11}$ The baseline Faulkender and Wang (2006) model is:

$$
\begin{aligned}
& r_{i, t}- R_{i, t}^{B}=\gamma_{0}+\gamma_{1} \frac{\Delta C_{i, t}}{M_{i, t-1}}+\gamma_{2} \frac{\Delta E_{i, t}}{M_{i, t-1}}+\gamma_{3} \frac{\Delta N A_{i, t}}{M_{i, t-1}}+\gamma_{4} \frac{\Delta R D_{i, t}}{M_{i, t-1}}+\gamma_{5} \frac{\Delta I_{i, t}}{M_{i, t-1}}+\gamma_{6} \frac{\Delta D_{i, t}}{M_{i, t-1}}+ \\
& \gamma_{7} \frac{\Delta C_{i, t-1}}{M_{i, t-1}}+\gamma_{8} L_{i, t}+\gamma_{9} \frac{\Delta N F_{i, t}}{M_{i, t-1}}+\varepsilon_{i, t}
\end{aligned}
$$

where $r_{i, t}-R_{i, t}^{B}$ is the excess stock return for firm i during fiscal year $\mathrm{t}$. The term $\Delta \mathrm{X}$ indicates changes in the variable $\mathrm{X}$. The $\mathrm{X}$ variables include cash holdings (C), earnings (E), net assets (NA), R\&D (RD), interest expense (I), dividend payment (D), financial leverage (L), and net financing (NF). Since both the dependent and the independent variables are standardized by lagged market value, the coefficient $\gamma_{1}$ measures the marginal value of one additional dollar cash holdings. In order to test our predictions we also include our forced turnover successor (Forced Turnover Successor) and outside industry (Outside Industry Successor) successor indicators. Regression results are provided in Table IX.

Model 1 of Table IX reports the baseline Faulkender and Wang (2006) model results, while Model 2 incorporates the forced turnover identifier and interacts the change in cash with the forced turnover identifier (Forced_succ* $\Delta \mathrm{Cash}_{\mathrm{t}}$ ). The coefficient on the interaction is insignificant,

\footnotetext{
${ }^{11}$ See Pinkowitz and Williamson (2007), Faulkender and Wang (2006), and Dittmar and Mahrt-Smith (2007), for example.
} 
indicating that the marginal value of cash is unchanged for successors following forced turnovers. Given that forced turnover successors are increasing cash holdings, these results indicate that they are not being penalized for doing so. We find similar results when examining inexperienced successors, as proxied by our outside industry identifier, following forced turnovers. Specifically, Model 3 incorporates outside industry successor related variables and the interaction between the change in cash holdings and forced turnover outside industry appointments (Forced_outind ${ }^{*} \Delta$ Cash $\left._{\mathrm{t}}\right)$. The statistically insignificant coefficient on the interaction term provides further evidence that the marginal value of their cash holdings is not discounted.

\section{Robustness}

\subsection{Addressing the endogeneity concern}

Changes in top management are often endogenously determined, so the board may simultaneously implement changes in both firm policy and top leadership. For this reason, it is difficult to conclude that the observed increase in cash holdings following forced departures can be attributed to CEO preferences as opposed to board decisions. We address this concern by using an instrument for forced turnovers. Such an instrument must affect the probability of a forced departure, but also must have no influence on cash holdings except for its effect on turnover. The difficulty of finding such an instrument arises from the fact that the observable firm-level variables that influence forced departure will most likely also have a direct influence on the level of firm cash holdings. For this reason, in the spirit of Peters and Wagner (2014), we utilize an industry level instrument for forced turnover. ${ }^{12}$ Specifically, we examine the lagged average industry long-

\footnotetext{
${ }^{12}$ Peters and Wagner (2014) also use industry level stock return volatility and semi-volatility as instruments for forced turnover when examining the relation between turnover and CEO compensation. We do not use these instruments due to their high correlation with cash flow volatility, which is positively related to cash holdings according to the precautionary motive for holding cash (e.g., see Han and Qiu, 2007).
} 
term credit ratings using the Fama and French 48 industry portfolios to determine industry classification. Higher levels of industry uncertainty risk (as proxied by the long-term credit ratings) should be positively related to the likelihood of forced departure (Jenter and Kanaan, 2015; Kaplan and Minton, 2012; and Eisfeldt and Kuhnen, 2013). We obtain credit ratings from Compustat and similar to Peters and Wagner, convert the ratings to integers values, scaling them by a factor of $1 / 9$.

In untabulated analysis, we replicate our main regression (Model 2 of Table 3) using a two stage least squares method. Results from the first stage regression yields a positive and significant coefficient on the industry long-term credit rating measure, indicating that higher industry level credit risk is associated with a higher likelihood of forced departure. The F-statistic on the excluded instrument is 34.37, which is above the cutoff point of 10 suggested by Stock, Wright, and Yogo (2002), indicating that the instrument is strong. Second stage regression results yield a positive and significant coefficient on the forced turnover instrument, which is consistent with our OLS results.

\subsection{Examining additional sources of cash holdings}

Weisbach (1995) finds that there is an increased probability of divesting poorly performing acquisitions following top management changes. An indirect result of such activity would be a temporary increase in cash for the divesting firm. ${ }^{13}$ In order to ensure that our results are not driven simply by an increase in asset divestures we revisit our analysis on the sources of cash holdings from Table VII. Specifically, we include write-down (Compustat item spi) to lagged assets and an interaction between write-downs and our forced turnover successor variable in Model 3 of Table

\footnotetext{
${ }^{13}$ Weisbach (1995) notes that the divesture of poorly performing acquisitions is just as likely for retirements as for resignations, indicating that divestures should not upwardly bias the level of cash holdings for the sample of forced departures.
} 
VII. In unreported results we find write-downs are significantly related to the change in cash holdings, but the interaction between forced turnover successors and write-downs is insignificant, indicating that forced turnover successors are no more likely to write-down assets when compared to their voluntary turnover counterparts. The coefficients and significance on all other variables of interest remain unchanged.

A second, but closely related concern is that the higher levels of cash holdings for successors following forced turnovers may be related to the strategy of "big bath" accounting, where successors manage earnings downward in the first year of their appointment in order to help increase earnings in following years (e.g., see Murphy and Zimmerman, 1993 and Pourcaiu, 1993). Such a strategy will largely influence the levels of non-cash discretionary accruals, but may also affect cash holdings through activities such as the sale of assets. As mentioned above, write-downs do not drive the level of cash holdings for forced turnover successors. However, in order to examine "big bath" accounting more closely we again revisit Table VII and incorporate extraordinary items and discontinued operations related to changes in cash (Compustat item xidoc) divided by lagged assets and an interaction between this variable and our forced turnover successor variable. The coefficients on both variables are insignificant and all other results remain unchanged, providing further support that the increase in cash holdings following forced turnovers are not driven by these activities.

Previous literature finds that the similarity of firms within the same industry and complexity of firm operations are related to both turnover and succession decisions (Parrino, 1997; Naveen, 2006; and Intintoli, 2013). Therefore, we examine Parrino's industry homogeneity measure and the sales based segment Herfindahl index used in Naveen (2006) to test whether our Table III regression results are robust to the inclusion of such controls. In untabulated results, we 
find that neither measure is significantly related to the level of cash holdings, but the inclusion of these variables does not materially change our main results.

\section{Conclusion}

How do executives influence their firms' cash holdings? A large number of researchers, such as Jensen (1986), argue that risk aversion motivates managers to keep excessive buffers. In contrast, more recent research argues that new CEOs are more likely to make costly operational mistakes, especially when they are outsiders who take over after forced departures, and the firm benefits from a larger buffer that protects it from financial distress.

We shed light on this subject by examining changes in cash holdings around CEO turnover. We find that cash holdings increase significantly following turnover, especially in cases of forced departures. The increase in cash holdings persists several years into the tenure of the successor and is robust to controls for the standard determinants of cash holdings as well as governance characteristics.

When we examine the determinants of cash holdings for successors following forced turnovers, we find that cash savings come mainly from changes in net working capital (decreases in inventory and accounts receivable). These results suggest that the increase in cash holdings following forced departures are the result of significant efficiencies in net working capital as opposed to a reduction in investment in fixed assets. Lastly, we estimate the value of cash holdings (Faulkender and Wang, 2006) for firms subject to CEO turnover. Regression results suggest that the marginal value of cash does not change following forced departures. Given that the marginal value of cash declines with larger cash holdings, our results suggest that the increase in cash holdings following managerial turnover is, on average, value enhancing. 


\section{References}

Adams, R., H. Almeida, and D. Ferreira, 2005, Powerful CEOs and their impact on corporate performance, Review of Financial Studies 18, 1403-1432.

Bates, T., K. Kahle, and R. Stulz, 2009, Why do U.S. firms hold so much more cash than they used to? Journal of Finance 64, no. 5, 1985-2022.

Bertrand, M., and A. Schoar, 2003, Managing with style: the effect of managers on firm policies, Quarterly Journal of Economics 118: 1169-1208.

Coles, J.L., N.D. Daniel, and L. Naveen, 2008. Boards: Does one size fit all?, Journal of Financial Economics, 87, 329-356..

Cronqvist, H., A. Makhija, and S. Yonker, 2012, Behavioral consistency in corporate finance: CEO personal and corporate leverage, Journal of Financial Economics 103, 20-40.

Cunha, I., and R.P. Ribas, 2012, Back in style (limited edition): Contrasts in style and CEO impact on corporate policy, Working Paper, Nova School of Business and Economics.

Custodio, C. and D. Metzger, 2013, How do CEOs matter? The effect of industry expertise on acquisition returns, Review of Financial Studies 26, 2008-2047

Dittmar, A., and R. Duchin, 2016, Looking in the rear view mirror: The effect of managers' professional experience on corporate cash holdings, Review of Financial Studies 29, 565-602.

Dittmar, A., and J. Mahrt-Smith, 2007, Corporate governance and the value of cash holdings, Journal of Financial Economics 83, 599-634.

Dittmar, A., J. Mahrt-Smith, and H. Servaes, 2003, International corporate governance and corporate cash holdings, Journal of Financial and Quantitative Analysis 38, 111-133.

Eisfeldt, A.L., and C.M. Kuhnen, 2013, CEO turnover in a competitive assignment framework, Journal of Financial Economics 109, 351-372.

Faulkender, M. and R. Wang, 2006, Corporate Financial Policy and the Value of Cash, Journal of Finance 61, 1957-1990.

Fee, C.E., C.J. Hadlock, and J.R. Pierce, 2013, Managers with and without style: Evidence using exogenous variation, Review of Financial Studies 26, 567-601.

Ganor, M., 2011, Agency costs in the era of economic crisis - The enhanced connection between CEO compensation and corporate cash holdings. Working Paper, University of Texas at Austin. 
Graham, J.R., Harvey, C.R., Puri, M., 2013, Managerial attitudes and corporate actions, Journal of Financial Economics 109, 103-121.

Han, S., and J. Qiu, 2007, Corporate precautionary cash holdings, Journal of Corporate Finance $13,43-57$.

Harford, J., S. Mansi, and W. Maxwell, 2008, Corporate governance and a firm's cash holdings, Journal of Financial Economics 87, 535-555.

Intintoli, V., 2013, The effects of succession choice surrounding CEO turnover announcements: Evidence from marathon successions, Financial Management 42, 211-238.

Jenter, D., and F. Kanaan, 2015, CEO turnover and relative performance evaluation, Journal of Finance 70, 2155-2184.

Jensen, M.C., 1986, The agency costs of free cash flow, corporate finance, and takeovers, American Economic Review 76, 323-329.

Kahle, K. and R. Stulz, 2013, Access to capital, investment, and the financial crisis, Journal of Financial Economics 110, 280-299.

Kaplan, S.N., and B.A. Minton, 2012, How has CEO turnover changed?, International Review of Finance 12, 57-82.

Malmendier, U., G. Tate, and J. Yang, 2011, Overconfidence and early-life experiences: The effect of managerial traits on corporate financial policies, Journal of Finance 66, 1687-1733.

McLean, R.D., 2011, Share Issuance and Cash Savings, Journal of Financial Economics 99, 693715.

Murphy, K. and J. Zimmerman, 1993, Financial performance surrounding CEO turnover, Journal of Accounting and Economics 16, 273-316.

Naveen, L., 2006, Organizational complexity and succession planning, Journal of Financial and Quantitative Analysis 41, 661-683.

Opler, T., L. Pinkowitz, R.M. Stulz, and R. Williamson, 1999, The determinants and implications of corporate cash holdings, Journal of Financial Economics 52, 3-46.

Parrino, R., 1997, CEO turnover and outside succession: a cross-sectional analysis, Journal of Financial Economics 46, 165-197.

Peters, F. and A. Wagner, 2014, The executive turnover risk premium, Journal of Finance 69, 1529-1563. 
Pinkowitz, L., R.M. Stulz, and R. Williamson, 2006, Do firms in countries with poor protection of investor rights hold more cash?, Journal of Finance 61, 2725-2751.

Pinkowitz, L. and R. Williamson, 2007, What is the market value of a dollar of corporate cash?, Journal of Applied Corporate Finance 19, 74-81.

Serfling, M., 2014, CEO age and the riskiness of corporate policies, Journal of Corporate Finance 25, 251-273.

Stock, J.H., J.H. Wright, and M. Yogo, 2002, A survey of weak instruments and weak identification in generalized method of moments, Journal of the American Statistical Assocation 20, 518-529.

Weisbach, M.S., 1995, CEO turnover and the firm's investment decisions, Journal of Financial Economics 37, 159-188. 


\section{Table I \\ Summary Statistics}

This table reports mean and median determinants of cash, firm characteristics, and executive-specific characteristics over predecessor ( $t=-4$ to -1 ) and successor ( $t=1$ to 4 ) tenure periods for our sample of 550 turnovers occurring from 1992-2003 ( $\mathrm{N}=4,344$ firm-year observations). All firm-specific and executivespecific variables are first averaged across executive years and variable definitions are provided in the Appendix. The year of the turnover $(t=0)$ is excluded since it represents a transition period for executives and it is unclear whether predecessor or successor policy is implemented at this time. p-values are provided for tests of the restriction that means (medians) for the predecessor and successor periods are drawn from different distributions, based on an analysis of variance (Wilcoxon rank-sum test).

\begin{tabular}{|c|c|c|c|c|c|c|c|c|}
\hline \multicolumn{9}{|c|}{ Panel A: Cash and Determinants of Cash } \\
\hline & \multicolumn{3}{|c|}{ Predecessor Tenure } & \multicolumn{3}{|c|}{ Successor Tenure } & \multicolumn{2}{|c|}{ Tests for Differences } \\
\hline & $\mathrm{N}$ & Mean & Median & $\mathrm{N}$ & Mean & Median & $\operatorname{Pr}>|\mathrm{t}|$ & $\operatorname{Pr}>|\mathrm{Z}|$ \\
\hline Cash / Assets & 550 & 0.0964 & 0.0449 & 550 & 0.1016 & 0.0526 & 0.4937 & 0.0453 \\
\hline Firm Size & 550 & 7688 & 2689 & 550 & 8819 & 3418 & 0.2302 & 0.0290 \\
\hline Market to Book & 550 & 2.2625 & 1.6754 & 550 & 2.0855 & 1.6845 & 0.0368 & 0.4644 \\
\hline Leverage & 550 & 0.2395 & 0.2274 & 550 & 0.2543 & 0.2491 & 0.1044 & 0.0525 \\
\hline Cash Flow / Assets & 550 & 0.0901 & 0.0881 & 550 & 0.0818 & 0.0849 & 0.0236 & 0.0281 \\
\hline Cash Flow Volatility & 545 & 0.0295 & 0.0212 & 547 & 0.0326 & 0.0230 & 0.1137 & 0.0153 \\
\hline Net Working Capital /Assets & 550 & 0.0882 & 0.0744 & 550 & 0.0573 & 0.0457 & 0.0000 & 0.0002 \\
\hline CAPEX / Assets & 550 & 0.0721 & 0.0619 & 550 & 0.0615 & 0.0515 & 0.0000 & 0.0000 \\
\hline R\&D / Sales & 550 & 0.0456 & 0.0066 & 550 & 0.0569 & 0.0067 & 0.4512 & 0.9116 \\
\hline Acquisitions / Assets & 526 & 0.0269 & 0.0099 & 523 & 0.0266 & 0.0126 & 0.8849 & 0.1113 \\
\hline Write-downs / Assets & 550 & -0.0136 & -0.0047 & 550 & -0.0218 & -0.0092 & 0.0000 & 0.0000 \\
\hline Dividends & 550 & 0.6944 & 1.0000 & 550 & 0.6772 & 1.0000 & 0.5255 & 0.4336 \\
\hline \multicolumn{9}{|c|}{ Panel B: Firm and Executive Specific Characteristics } \\
\hline & \multicolumn{3}{|c|}{$\begin{array}{c}\text { Predecessor Tenure } \\
\end{array}$} & \multicolumn{3}{|c|}{ Successor Tenure } & \multicolumn{2}{|c|}{ Tests for Differences } \\
\hline & $\mathrm{N}$ & Mean & Median & $\mathrm{N}$ & Mean & Median & $\operatorname{Pr}>|\mathrm{t}|$ & $\operatorname{Pr}>|\mathrm{Z}|$ \\
\hline CEO Age & 550 & 60.07 & 61.00 & 550 & 50.77 & 51.00 & 0.0001 & 0.0001 \\
\hline Member of Founding Family & 550 & 0.1073 & 0.0000 & 550 & 0.0327 & 0.0000 & 0.0001 & 0.0001 \\
\hline Dual CEO/Chairman & 542 & 0.7720 & 1.0000 & 539 & 0.5776 & 0.6667 & 0.0001 & 0.0001 \\
\hline Board Size & 527 & 10.51 & 10.50 & 488 & 10.32 & 10.00 & 0.2352 & 0.2512 \\
\hline Percentage of Outside Directors & 527 & 0.7475 & 0.7734 & 488 & 0.7831 & 0.8002 & 0.0001 & 0.0001 \\
\hline Blockholder Ownership & 526 & 0.2831 & 0.2424 & 485 & 0.3166 & 0.2895 & 0.0157 & 0.0026 \\
\hline
\end{tabular}




\section{Table II}

\section{Pre- to Post-Turnover Changes in Cash and the Determinants of Cash}

This table reports the determinants of cash over the predecessor ( $t=-4$ to -1 ) and successor ( $t=1$ to 4 ) tenure periods. All variables are first averaged across executive years. Forced CEO turnovers are defined as departures that are (1) explicitly identified in the Wall Street Journal as being forced, or (2) instances where the incumbent is less than 60 and the reason for departure is not specified as being due to poor health, death, or the acceptance of a new position. All other variable definitions are provided in the Appendix. The year of the turnover $(t=0)$ is excluded since it represents a transition period for executives and it is unclear whether predecessor or successor policy is implemented at this time. p-values are provided for tests of the restriction that means (medians) for the predecessor and successor periods are drawn from different distributions, based on an analysis of variance (Wilcoxon rank-sum test). Superscripts (a $\mathrm{p}<0.01$, b $\mathrm{p}<0.05$, с $\mathrm{p}<0.10$ ) are provided in Panel A for tests that means (medians) for (1) forced turnover predecessor versus the voluntary turnover predecessor and (2) forced turnover successor versus the voluntary turnover successor periods are drawn from different distributions, based on an analysis of variance (Wilcoxon ranksum test).

\begin{tabular}{|c|c|c|c|c|c|c|c|c|}
\hline \multicolumn{9}{|l|}{ Panel A: Forced Turnovers } \\
\hline & \multicolumn{3}{|c|}{ Predecessor Tenure } & \multicolumn{3}{|c|}{ Successor Tenure } & \multicolumn{2}{|c|}{ Tests for Differences } \\
\hline & $\mathrm{N}$ & Mean & Median & $\mathrm{N}$ & Mean & Median & $\operatorname{Pr}>|t|$ & $\operatorname{Pr}>|\mathrm{Z}|$ \\
\hline Cash / Assets & $\overline{109}$ & 0.0965 & 0.0517 & 109 & $0.1294^{\mathrm{a}}$ & $0.0999^{\mathrm{a}}$ & 0.0370 & 0.0118 \\
\hline Firm size & 109 & 9401 & 3283 & 109 & 8964 & 3320 & 0.8275 & 0.7071 \\
\hline Market to Book & 109 & 2.1671 & 1.6622 & 109 & $1.8099^{\mathrm{a}}$ & $1.5628^{\mathrm{a}}$ & 0.0394 & 0.3036 \\
\hline Leverage & 109 & $0.2710^{\mathrm{b}}$ & $0.2615^{\mathrm{b}}$ & 109 & $0.2871^{\mathrm{b}}$ & 0.2514 & 0.5129 & 0.5519 \\
\hline Cash Flow / Assets & 109 & 0.0892 & 0.0843 & 109 & $0.0673^{\mathrm{a}}$ & $0.0691^{\mathrm{a}}$ & 0.0054 & 0.0148 \\
\hline Cash Flow Volatility & 108 & 0.0299 & 0.0244 & 108 & $0.0435^{\mathrm{a}}$ & $0.0274^{\mathrm{a}}$ & 0.0041 & 0.0200 \\
\hline Net Working Capital /Assets & 109 & 0.0864 & 0.0791 & 109 & $0.0338^{\mathrm{b}}$ & $0.0322^{\mathrm{C}}$ & 0.0052 & 0.0022 \\
\hline CAPEX / Assets & 109 & 0.0701 & 0.0612 & 109 & 0.0572 & 0.0495 & 0.0229 & 0.0089 \\
\hline R\&D / Sales & 109 & 0.0421 & 0.0058 & 109 & 0.0455 & 0.0053 & 0.7502 & 0.9991 \\
\hline Acquisitions / Assets & 106 & 0.0275 & 0.0098 & 107 & $0.0160^{\mathrm{a}}$ & $0.0069^{\mathrm{a}}$ & 0.0183 & 0.4157 \\
\hline Write-downs / Assets & 109 & -0.0201 & -0.0095 & 109 & -0.0331 & -0.0185 & 0.0144 & 0.0017 \\
\hline Dividends & 109 & $0.6032^{\mathrm{b}}$ & $1.0000^{\mathrm{b}}$ & 109 & $0.5326^{\mathrm{a}}$ & $0.8000^{\mathrm{a}}$ & 0.2781 & 0.2791 \\
\hline CEO Age & 109 & $54.30^{\mathrm{a}}$ & $55.00^{\mathrm{a}}$ & 109 & 50.11 & 50.00 & 0.0001 & 0.0001 \\
\hline Member of Founding Family & 109 & 0.0734 & 0.0000 & 109 & 0.0183 & 0.0000 & 0.0524 & 0.0530 \\
\hline Dual CEO/Chairman & 108 & $0.6265^{\mathrm{a}}$ & $1.0000^{\mathrm{a}}$ & 107 & $0.5020^{\mathrm{b}}$ & $0.6000^{\mathrm{C}}$ & 0.0382 & 0.0326 \\
\hline Board Size & 96 & $9.92^{b}$ & $9.88^{\mathrm{b}}$ & 88 & $9.69^{\mathrm{a}}$ & $9.45^{\mathrm{a}}$ & 0.5618 & 0.4189 \\
\hline Percentage of Outside Directors & 96 & 0.7477 & 0.7714 & 88 & 0.7938 & 0.8153 & 0.0054 & 0.0049 \\
\hline Blockholder Ownership & 95 & 0.2914 & 0.2736 & 86 & 0.3382 & 0.3183 & 0.1305 & 0.1596 \\
\hline
\end{tabular}


Table II continued

\begin{tabular}{|c|c|c|c|c|c|c|c|c|}
\hline \multicolumn{9}{|l|}{ Panel B: Voluntary Turnovers } \\
\hline & \multicolumn{3}{|c|}{ Predecessor Tenure } & \multicolumn{3}{|c|}{ Successor Tenure } & \multicolumn{2}{|c|}{ Tests for Differences } \\
\hline & $\mathrm{N}$ & Mean & Median & $\mathrm{N}$ & Mean & Median & $\operatorname{Pr}>|t|$ & $\operatorname{Pr}>|\mathrm{Z}|$ \\
\hline Cash / Assets & 441 & 0.0964 & 0.0438 & 441 & 0.0947 & 0.0479 & 0.8422 & 0.3137 \\
\hline Firm size & 441 & 7264 & 2642 & 441 & 8783 & 3480 & 0.1548 & 0.0239 \\
\hline Market to Book & 441 & 2.2861 & 1.6835 & 441 & 2.1536 & 1.7091 & 0.1697 & 0.7797 \\
\hline Leverage & 441 & 0.2318 & 0.2234 & 441 & 0.2462 & 0.2487 & 0.1295 & 0.0511 \\
\hline Cash Flow Volatility & 437 & 0.0294 & 0.0205 & 439 & 0.0299 & 0.0221 & 0.8014 & 0.1036 \\
\hline Cash Flow / Assets & 441 & 0.0903 & 0.0901 & 441 & 0.0854 & 0.0860 & 0.2295 & 0.2119 \\
\hline Net Working Capital /Assets & 441 & 0.0886 & 0.0726 & 441 & 0.0631 & 0.0532 & 0.0042 & 0.0086 \\
\hline CAPEX / Assets & 441 & 0.0726 & 0.0622 & 441 & 0.0626 & 0.0522 & 0.0005 & 0.0001 \\
\hline R\&D / Sales & 441 & 0.0465 & 0.0067 & 441 & 0.0597 & 0.0067 & 0.4744 & 0.9018 \\
\hline Acquisitions / Assets & 420 & 0.0268 & 0.0099 & 416 & 0.0293 & 0.0159 & 0.3507 & 0.0253 \\
\hline Write-downs / Assets & 441 & -0.0120 & -0.0037 & 441 & -0.0190 & -0.0084 & 0.0015 & 0.0000 \\
\hline Dividends & 441 & 0.7169 & 1.0000 & 441 & 0.7129 & 1.0000 & 0.8918 & 0.7446 \\
\hline CEO Age & 441 & 61.50 & 63.00 & 441 & 50.93 & 51.00 & 0.0001 & 0.0001 \\
\hline Member of Founding Family & 441 & 0.1156 & 0.0000 & 441 & 0.0363 & 0.0000 & 0.0001 & 0.0001 \\
\hline Dual CEO/Chairman & 434 & 0.8082 & 1.0000 & 432 & 0.5963 & 0.7500 & 0.0001 & 0.0001 \\
\hline Board Size & 431 & 10.65 & 10.75 & 400 & 10.46 & 10.29 & 0.2926 & 0.3678 \\
\hline Percentage of Outside Directors & 431 & 0.7475 & 0.7734 & 400 & 0.7807 & 0.7976 & 0.0001 & 0.0001 \\
\hline Blockholder Ownership & 431 & 0.2812 & 0.2318 & 399 & 0.3119 & 0.2798 & 0.0479 & 0.0075 \\
\hline
\end{tabular}




\section{Regressions on the Executive Specific Determinants of Cash Holdings}

This table provides OLS regression results on the determinants of cash holdings controlling for both firm and year fixed effects. The dependent variable is the ratio of cash to assets. Forced turnover successor is an indicator variable set equal to 1 for successors that are appointed after forced turnovers. Outside industry successor is an indicator variable equal to 1 for successors that were previously appointed in an industry that differs from their new appointment. Forced_Succ*Outside_Ind is an interaction between the forced turnover successor and outside industry successor variables. Outside_Ind*R\&D is an interaction between the outside industry successor variable and a dummy variable set equal to 1 for non zero R\&D firms. CEO age $>=60$ and $C E O$ is also Chairman are indicator variables set equal to 1 if the executive is at least 60 years old and if the current CEO also holds the Chairman post. Forced_Succ*CEO_Chair is an interaction between the forced turnover successor and CEO duality variables. Definitions of all other independent variables are provided in the Appendix. The year of the turnover $(\mathrm{t}=0)$ is excluded since it represents a transition period for executives and it is unclear whether predecessor or successor policy is implemented at this time. p-values based on standard errors robust to clustering at the firm level are provided in parentheses. 


\begin{tabular}{|c|c|c|c|c|c|c|c|}
\hline Independent Variable & Model 1 & Model 2 & Model 3 & Model 4 & Model 5 & Model 6 & Model 7 \\
\hline \multirow[t]{2}{*}{ Intercept } & 0.292 & $\overline{0.271}$ & 0.270 & 0.274 & 0.270 & 0.150 & 0.147 \\
\hline & $(0.000)$ & $(0.000)$ & $(0.000)$ & $(0.000)$ & $(0.000)$ & $(0.028)$ & $(0.032)$ \\
\hline \multirow[t]{2}{*}{ Ln(Market Cap.) } & -0.014 & -0.013 & -0.013 & -0.013 & -0.012 & 0.005 & 0.005 \\
\hline & $(0.078)$ & $(0.108)$ & $(0.108)$ & $(0.103)$ & $(0.158)$ & $(0.544)$ & $(0.527)$ \\
\hline \multirow[t]{2}{*}{ Leverage } & -0.159 & -0.157 & -0.158 & -0.159 & -0.157 & -0.163 & -0.163 \\
\hline & $(0.000)$ & $(0.000)$ & $(0.000)$ & $(0.000)$ & $(0.000)$ & $(0.000)$ & $(0.000)$ \\
\hline \multirow[t]{2}{*}{ Market to Book } & 0.008 & 0.009 & 0.009 & 0.009 & 0.009 & 0.010 & 0.010 \\
\hline & $(0.000)$ & $(0.000)$ & $(0.000)$ & $(0.000)$ & $(0.000)$ & $(0.002)$ & $(0.002)$ \\
\hline \multirow[t]{2}{*}{ Cash Flow/Assets } & 0.015 & 0.020 & 0.020 & 0.018 & 0.016 & -0.006 & -0.007 \\
\hline & $(0.704)$ & $(0.611)$ & $(0.614)$ & $(0.651)$ & $(0.673)$ & $(0.891)$ & $(0.857)$ \\
\hline \multirow[t]{2}{*}{ Net Working Capital/Assets } & -0.222 & -0.218 & -0.218 & -0.215 & -0.216 & -0.231 & -0.233 \\
\hline & $(0.000)$ & $(0.000)$ & $(0.000)$ & $(0.000)$ & $(0.000)$ & $(0.000)$ & $(0.000)$ \\
\hline \multirow[t]{2}{*}{ Cash Flow Volatility } & 0.186 & 0.150 & 0.147 & 0.135 & 0.137 & 0.112 & 0.105 \\
\hline & $(0.048)$ & $(0.108)$ & $(0.111)$ & $(0.143)$ & $(0.134)$ & $(0.395)$ & $(0.420)$ \\
\hline \multirow[t]{2}{*}{ R\&D/Sales } & 0.014 & 0.014 & 0.014 & 0.013 & - & 0.003 & 0.003 \\
\hline & $(0.167)$ & $(0.165)$ & $(0.165)$ & $(0.212)$ & - & $(0.851)$ & $(0.836)$ \\
\hline \multirow[t]{2}{*}{ CAPEX / Assets } & -0.351 & -0.346 & -0.345 & -0.336 & -0.346 & -0.301 & -0.298 \\
\hline & $(0.000)$ & $(0.000)$ & $(0.000)$ & $(0.000)$ & $(0.000)$ & $(0.000)$ & $(0.000)$ \\
\hline \multirow[t]{2}{*}{ Dividends } & -0.026 & -0.025 & -0.025 & -0.025 & -0.026 & -0.034 & -0.034 \\
\hline & $(0.009)$ & $(0.015)$ & $(0.015)$ & $(0.013)$ & $(0.013)$ & $(0.025)$ & $(0.022)$ \\
\hline \multirow[t]{2}{*}{ Forced Turnover Successor } & - & 0.026 & 0.025 & 0.017 & 0.025 & 0.021 & 0.041 \\
\hline & - & $(0.002)$ & $(0.001)$ & $(0.035)$ & $(0.001)$ & $(0.021)$ & $(0.014)$ \\
\hline \multirow[t]{2}{*}{ Outside Industry Successor } & - & - & 0.004 & -0.010 & -0.014 & - & - \\
\hline & - & - & $(0.667)$ & $(0.233)$ & $(0.187)$ & - & - \\
\hline \multirow[t]{2}{*}{ Forced_Succ*Outside_Ind } & - & - & - & 0.043 & - & - & - \\
\hline & - & - & - & $(0.067)$ & - & - & - \\
\hline \multirow[t]{2}{*}{ R\&D Dummy } & - & - & - & - & -0.018 & - & - \\
\hline & - & - & - & - & $(0.170)$ & - & - \\
\hline \multirow[t]{2}{*}{ Outside_Ind*R\&D } & - & - & - & - & 0.030 & - & - \\
\hline & - & - & - & - & $(0.063)$ & - & - \\
\hline \multirow[t]{2}{*}{ CEO Age $>=60$} & - & - & - & - & - & 0.007 & 0.007 \\
\hline & - & - & - & - & - & $(0.079)$ & $(0.072)$ \\
\hline \multirow[t]{2}{*}{ CEO Duality } & - & - & - & - & - & 0.000 & 0.003 \\
\hline & - & - & - & - & - & $(0.968)$ & $(0.560)$ \\
\hline \multirow[t]{2}{*}{ Forced_Succ*CEO_Chair } & - & - & - & - & - & - & -0.029 \\
\hline & - & - & - & - & - & - & $(0.097)$ \\
\hline \multirow[t]{2}{*}{ Founding Family CEO } & - & - & - & - & - & 0.003 & 0.002 \\
\hline & - & - & - & - & - & $(0.807)$ & $(0.857)$ \\
\hline \multirow[t]{2}{*}{ Board Size } & - & - & - & - & - & 0.004 & 0.004 \\
\hline & - & - & - & - & - & $(0.592)$ & $(0.615)$ \\
\hline \multirow[t]{2}{*}{ Board Independence } & - & - & - & - & - & -0.020 & -0.019 \\
\hline & - & - & - & - & - & $(0.188)$ & $(0.198)$ \\
\hline Blockholder Ownership & - & - & - & - & - & -0.001 & -0.001 \\
\hline & - & - & - & - & - & $(0.939)$ & $(0.929)$ \\
\hline Year controls & Yes & Yes & Yes & Yes & Yes & Yes & Yes \\
\hline Firm level controls & Yes & Yes & Yes & Yes & Yes & Yes & Yes \\
\hline Number of firm year observati & 3,769 & 3,769 & 3,769 & 3,769 & 3,769 & 2,618 & 2,618 \\
\hline Adj. $R 2$ & 0.416 & 0.461 & 0.461 & 0.461 & 0.416 & 0.342 & 0.336 \\
\hline
\end{tabular}




\section{Table IV}

Predicted Cash Ratios and Deviations from Predicted Ratios across Predecessor and Successor Periods

This table reports the predicted cash ratios and deviations from actual cash ratios from an out of sample model for each year $\mathrm{t}=-4$ to +4 relative to the turnover year $(\mathrm{t}=0)$ for all firm-year observations (with available data) for the entire sample $(\mathrm{N}=3,852)$, sample of forced turnovers $(\mathrm{N}=726)$, and sample of voluntary turnovers ( $\mathrm{N}=3,126)$. As in Bates, Kahle, and Stulz (2009), we derive annual predicted cash ratios from a Fama-MacBeth model predicting the cash ratios using coefficients from annual cross sectional regressions from 1980-1989 for all Compustat non-financial, non-utility firms. Regression estimates are: Cash ratio $=0.307+0.230$ Industry Cash Flow Volatility +0.006 Market to Book -0.009 Log Firm Size +0.077 Cash Flow/Assets - 0.238 Net Working Capital/Assets - 0.372 CAPEX/Assets - 0.360 Leverage + 0.048 R\&D/Sales -0.024 Dividend Dummy 0.233 Acquisitions/Assets + 0.158 Net Equity/Assets + 0.190 Net Debt/Assets. t-statistics provide the statistical significance for tests of differences between the predicted and actual cash ratios for the entire sample and forced turnover sample, respectively.

\begin{tabular}{|c|c|c|c|c|c|c|c|c|c|}
\hline \multirow[b]{2}{*}{$\begin{array}{l}\text { Year Relative } \\
\text { to Departure }\end{array}$} & \multicolumn{3}{|c|}{ Entire Sample } & \multicolumn{3}{|c|}{ Forced Turnovers } & \multicolumn{3}{|c|}{ Voluntary Turnovers } \\
\hline & Predicted & $\begin{array}{c}\text { Actual - } \\
\text { Predicted } \\
\end{array}$ & t-statistic & Predicted & $\begin{array}{c}\text { Actual - } \\
\text { Predicted }\end{array}$ & t-statistic & Predicted & $\begin{array}{c}\text { Actual - } \\
\text { Predicted }\end{array}$ & t-statistic \\
\hline-4 & 0.130 & -0.024 & -4.45 & 0.128 & 0.012 & 0.46 & 0.130 & -0.030 & -5.13 \\
\hline-3 & 0.128 & -0.034 & -7.26 & 0.130 & -0.019 & -1.66 & 0.128 & -0.037 & -7.18 \\
\hline-2 & 0.129 & -0.034 & -7.69 & 0.118 & -0.021 & -2.38 & 0.131 & -0.038 & -7.33 \\
\hline-1 & 0.127 & -0.039 & -9.56 & 0.113 & -0.019 & -2.35 & 0.131 & -0.044 & -9.49 \\
\hline 0 & 0.127 & -0.035 & -8.47 & 0.118 & -0.014 & -1.54 & 0.129 & -0.041 & -8.75 \\
\hline 1 & 0.131 & -0.033 & -7.56 & 0.124 & -0.010 & -1.07 & 0.133 & -0.039 & -7.92 \\
\hline 2 & 0.131 & -0.027 & -5.72 & 0.130 & 0.005 & 0.50 & 0.132 & -0.035 & -6.88 \\
\hline 3 & 0.134 & -0.028 & -5.58 & 0.132 & 0.022 & 1.65 & 0.134 & -0.039 & -7.78 \\
\hline 4 & 0.134 & -0.023 & -4.18 & 0.130 & 0.026 & 1.66 & 0.135 & -0.034 & -6.15 \\
\hline
\end{tabular}




\section{Table V}

\section{Level of Cash Holdings Surrounding Turnover}

This table provides event time regression results on the change in cash holdings around forced and voluntary turnovers. Panel A uses the following specification: $Y_{i t}=\alpha+\sum_{\eta=-N}^{+N} \beta_{\eta}^{F} F_{i \eta}+\sum_{\eta=-N}^{+N} \beta_{\eta}^{V} V_{i \eta}+\beta^{\prime} X_{i t}+\varepsilon_{i t}$. The dependent variable, $Y_{i t}$ is cash to assets. The notation $\eta$ represents the year relative to the CEO turnover and spans from $-N$ to $+N$, where $-N$ begins three years prior to the turnover and $+N$ ends three years after the turnover. $F_{i \eta}$ and $V_{i \eta}$ are indicator variables set equal to 1 for forced $\left(F_{i \eta}\right)$ and voluntary $\left(V_{i \eta}\right)$ turnover firms $i$ in year $\eta$. The coefficients on these variables represent the annual specific cash holdings for firms where the CEO is forced out or departs voluntarily. Panel B aggregates the annual cash holdings into predecessor $\left(\beta^{\mathrm{F}}-\beta_{-}^{\mathrm{V}}\right)$ and successor $\left(\beta^{\mathrm{F}_{+}}-\beta^{\mathrm{V}_{+}}\right)$periods using the following equation: $Y_{i t}=\beta_{-}^{F} F_{-}+\beta_{+}^{F} F_{+}+\beta_{-}^{V} V_{-}+\beta_{+}^{V} V_{+}+\beta^{\prime} X_{i t}+\varepsilon_{i t}$. Additional control variables $\left(\mathrm{X}_{i t}\right)$ for both models include firm and year fixed effects (Models 1-3), previously identified determinants of cash (Models 2-3), and CEO and governance characteristics (Model 3). Determinants of cash, CEO characteristics, and governance characteristics are shown in Table III. Panel B excludes the year of the turnover $(t=0)$ since it represents a transition period for executives and it is unclear whether predecessor or successor policy is implemented at this time. p-values from Wald statistics using standard errors clustered at the firm level are provided in parentheses. Annual estimates of the coefficient differences from Panel A are graphically represented in Figure 1.

\begin{tabular}{|c|c|c|c|}
\hline \multicolumn{4}{|c|}{ Panel A: Yearly Cash Holdings Surrounding the Turnover $(\mathrm{t}=0$ ) } \\
\hline & Model 1 & Model 2 & Model 3 \\
\hline$\beta_{-3}^{F}-\beta_{-3}^{V}$ & -0.0234 & -0.0068 & -0.0096 \\
\hline & (0.029) & $(0.472)$ & $(0.425)$ \\
\hline$\beta_{-2}^{F}-\beta_{-2}^{V}$ & -0.0193 & -0.0022 & -0.0039 \\
\hline & $(0.050)$ & $(0.805)$ & $(0.717)$ \\
\hline$\beta_{-1}^{F}-\beta_{-1}^{V}$ & -0.0156 & 0.0010 & -0.0011 \\
\hline & $(0.095)$ & $(0.902)$ & $(0.905)$ \\
\hline$\beta_{0}^{F}-\beta_{0}^{V}$ & -0.0049 & 0.0003 & -0.0058 \\
\hline$\beta_{1}^{F}-\beta_{1}^{V}$ & $\begin{array}{c}(0.577) \\
-0.0027\end{array}$ & $\begin{array}{l}(0.977) \\
-0.0008\end{array}$ & $\begin{array}{c}(0.603) \\
-0.0109\end{array}$ \\
\hline & $(0.785)$ & $(0.931)$ & $(0.262)$ \\
\hline$\beta_{2}^{F}-\beta_{2}^{v}$ & 0.0193 & 0.0137 & 0.0208 \\
\hline & $(0.035)$ & $(0.119)$ & $(0.028)$ \\
\hline$-\beta_{3}^{V}$ & 0.0493 & 0.0415 & 0.0400 \\
\hline & $(0.000)$ & $(0.000)$ & $(0.002)$ \\
\hline Year controls & Yes & Yes & Yes \\
\hline Firm level controls & Yes & Yes & Yes \\
\hline Determinants of Cash Controls & No & Yes & Yes \\
\hline CEO and Governance Controls & No & No & Yes \\
\hline Firm year observations & 4,344 & 4,344 & 2,887 \\
\hline Adj. $R 2$ & 0.0364 & 0.5338 & 0.5609 \\
\hline
\end{tabular}


Table V continued

\begin{tabular}{|c|c|c|c|}
\hline \multicolumn{4}{|c|}{ Panel B: Pre- to Post-Turnover Period Cash Holdings } \\
\hline & Model 1 & Model 2 & Model 3 \\
\hline$\beta^{F} .-\beta^{V}$. & -0.0055 & 0.0087 & 0.0033 \\
\hline & $(0.448)$ & $(0.172)$ & $(0.663)$ \\
\hline$\beta_{+}^{\mathrm{F}}-\beta_{+}^{\mathrm{V}}$ & 0.0346 & 0.0266 & 0.0221 \\
\hline & $(0.000)$ & $(0.000)$ & $(0.008)$ \\
\hline$\left(\beta_{+}^{F}-\beta_{+}^{V}\right)-$ & 0.0401 & 0.0179 & 0.0188 \\
\hline$\left(\beta_{-}^{F}-\beta_{-}^{V}\right)$ & $(0.000)$ & $(0.035)$ & $(0.092)$ \\
\hline Year controls & Yes & Yes & Yes \\
\hline Firm level controls & Yes & Yes & Yes \\
\hline Determinants of Cash Controls & No & Yes & Yes \\
\hline CEO and Governance Controls & No & No & Yes \\
\hline Firm year observations & 3,530 & 3,505 & 2,402 \\
\hline Adj. $R 2$ & 0.0330 & 0.5063 & 0.5263 \\
\hline
\end{tabular}




\section{Table VI}

\section{Examining Sources of Cash}

This table provides summary statistics for predecessor and successor period sources of cash holdings. All firm-specific and executive-specific variables are first averaged across executive years and variable definitions are provided in the Appendix. All variables are winsorized at the $1 \%$ and $99 \%$ levels and the year of the turnover $(t=0)$ is excluded from the sample since it represents a transition period for executives and it is unclear whether predecessor or successor policy is implemented at this time. Components of current assets exclude cash. p-values are provided for tests of the restriction that means (medians) for the predecessor and successor periods are drawn from different distributions, based on an analysis of variance (Wilcoxon rank-sum test).

\begin{tabular}{|c|c|c|c|c|c|c|c|c|}
\hline & \multicolumn{3}{|c|}{ Predecessor Tenure } & \multicolumn{3}{|c|}{ Successor Tenure } & \multicolumn{2}{|c|}{ Tests for Differences } \\
\hline & $\mathrm{N}$ & Mean & Median & $\mathrm{N}$ & Mean & Median & $\operatorname{Pr}>|t|$ & $\operatorname{Pr}>|\mathrm{Z}|$ \\
\hline Net Issue & 107 & -0.0148 & -0.0103 & 105 & -0.0161 & -0.0100 & 0.8692 & 0.6607 \\
\hline Net Debt & 107 & 0.0258 & 0.0147 & 105 & -0.0039 & -0.0062 & 0.0000 & 0.0000 \\
\hline Net Sale PP\&E & 107 & -0.0781 & -0.0646 & 105 & -0.0514 & -0.0394 & 0.0000 & 0.0000 \\
\hline Cash Flow & 107 & 0.1075 & 0.0958 & 105 & 0.0721 & 0.0783 & 0.0012 & 0.0044 \\
\hline CA / Assets & 107 & 0.4223 & 0.4141 & 105 & 0.3389 & 0.3241 & 0.0002 & 0.0025 \\
\hline AR / Assets & 106 & 0.2056 & 0.1958 & 105 & 0.1601 & 0.1525 & 0.0025 & 0.0045 \\
\hline Inventory / Assets & 106 & 0.1652 & 0.1163 & 105 & 0.1271 & 0.0919 & 0.0515 & 0.0427 \\
\hline Other CA / Assets & 107 & 0.0483 & 0.0419 & 105 & 0.0497 & 0.0467 & 0.7421 & 0.6097 \\
\hline CL / Assets & 107 & 0.3145 & 0.3082 & 105 & 0.3033 & 0.2936 & 0.5247 & 0.7034 \\
\hline ST-Debt / Assets & 107 & 0.0537 & 0.0456 & 105 & 0.0436 & 0.0234 & 0.1635 & 0.0517 \\
\hline AP / Assets & 107 & 0.1102 & 0.0810 & 105 & 0.1043 & 0.0782 & 0.6419 & 0.6526 \\
\hline Other CL / Assets & 107 & 0.1346 & 0.1189 & 105 & 0.1376 & 0.1180 & 0.7477 & 0.7403 \\
\hline \multicolumn{9}{|c|}{ Panel B: Voluntary Turnovers } \\
\hline & \multicolumn{3}{|c|}{ Predecessor Tenure } & \multicolumn{3}{|c|}{ Successor Tenure } & \multicolumn{2}{|c|}{ Tests for Differences } \\
\hline & $\mathrm{N}$ & Mean & Median & $\mathrm{N}$ & Mean & Median & $\operatorname{Pr}>|t|$ & $\operatorname{Pr}>|\mathrm{Z}|$ \\
\hline Net Issue & $\overline{434}$ & -0.0254 & -0.0225 & $\overline{428}$ & -0.0323 & -0.0249 & 0.0685 & 0.1700 \\
\hline Net Debt & 434 & 0.0172 & 0.0076 & 428 & 0.0170 & 0.0077 & 0.9537 & 0.9597 \\
\hline Net Sale PP\&E & 434 & -0.0790 & -0.0655 & 428 & -0.0631 & -0.0505 & 0.0000 & 0.0000 \\
\hline Cash Flow & 434 & 0.1227 & 0.1175 & 428 & 0.1078 & 0.1044 & 0.0031 & 0.0023 \\
\hline CA / Assets & 434 & 0.3938 & 0.3878 & 428 & 0.3416 & 0.3313 & 0.0000 & 0.0000 \\
\hline AR / Assets & 433 & 0.1852 & 0.1708 & 427 & 0.1607 & 0.1470 & 0.0010 & 0.0022 \\
\hline Inventory / Assets & 432 & 0.1616 & 0.1346 & 427 & 0.1368 & 0.1102 & 0.0066 & 0.0097 \\
\hline Other CA / Assets & 434 & 0.0434 & 0.0367 & 428 & 0.0423 & 0.0346 & 0.5865 & 0.7371 \\
\hline CL / Assets & 434 & 0.2920 & 0.2731 & 428 & 0.2755 & 0.2648 & 0.0435 & 0.1221 \\
\hline ST-Debt / Assets & 434 & 0.0425 & 0.0281 & 428 & 0.0402 & 0.0261 & 0.4624 & 0.3850 \\
\hline AP / Assets & 434 & 0.1033 & 0.0845 & 428 & 0.0941 & 0.0786 & 0.0613 & 0.0299 \\
\hline Other CL / Assets & 434 & 0.1260 & 0.1126 & 428 & 0.1244 & 0.1138 & 0.7424 & 0.9519 \\
\hline
\end{tabular}




\section{Table VII}

\section{Regressions on Sources of Cash}

This table provides Fama-MacBeth regression results for changes in cash holdings on sources of cash. The dependent variable is the percentage change in cash holdings, measured by $\left(\operatorname{cash}_{t}-\operatorname{cash}_{\mathrm{t}-1}\right) /\left(\right.$ assets $\left._{\mathrm{t}-1}\right)$. For_succ*Chg_nwc, For_succ*Net_issue, For_succ*Net_debt, For_succ*Net_PP\&E, and For_succ *Cashflow are interactions between Forced Turnover Successor and Change in NWC, Net Issue, Net Debt, and Sale of PPE, and Cash flow, respectively. Definitions of all other independent variables are provided in the Appendix. The year of the turnover $(\mathrm{t}=0)$ is excluded from the sample since it represents a transition period for executives and it is unclear whether predecessor or successor policy is implemented at this time. All variables are winsorized at the $1 \%$ and $99 \%$ levels.

\begin{tabular}{|c|c|c|c|c|c|c|c|c|}
\hline Independent Variable & Model 1 & Model 2 & Model 3 & Model 4 & Model 5 & Model 6 & Model 7 & Model 9 \\
\hline Constant & $\begin{array}{c}0.003 \\
(0.746)\end{array}$ & $\begin{array}{c}0.005 \\
(0.583)\end{array}$ & $\begin{array}{c}0.004 \\
(0.662)\end{array}$ & $\begin{array}{c}0.003 \\
(0.786)\end{array}$ & $\begin{array}{c}0.004 \\
(0.651)\end{array}$ & $\begin{array}{c}0.004 \\
(0.647)\end{array}$ & $\begin{array}{c}0.004 \\
(0.679)\end{array}$ & $\begin{array}{c}0.004 \\
(0.685)\end{array}$ \\
\hline Net Issue & $\begin{array}{c}0.403 \\
(0.000)\end{array}$ & $\begin{array}{c}0.467 \\
(0.000)\end{array}$ & $\begin{array}{c}0.467 \\
(0.000)\end{array}$ & $\begin{array}{c}0.464 \\
(0.000)\end{array}$ & $\begin{array}{c}0.471 \\
(0.000)\end{array}$ & $\begin{array}{c}0.468 \\
(0.000)\end{array}$ & $\begin{array}{c}0.468 \\
(0.000)\end{array}$ & $\begin{array}{c}0.463 \\
(0.000)\end{array}$ \\
\hline Net Debt & $\begin{array}{c}0.112 \\
(0.001)\end{array}$ & $\begin{array}{c}0.139 \\
(0.000)\end{array}$ & $\begin{array}{c}0.140 \\
(0.000)\end{array}$ & $\begin{array}{c}0.142 \\
(0.000)\end{array}$ & $\begin{array}{c}0.140 \\
(0.000)\end{array}$ & $\begin{array}{c}0.135 \\
(0.000)\end{array}$ & $\begin{array}{c}0.140 \\
(0.000)\end{array}$ & $\begin{array}{c}0.142 \\
(0.000)\end{array}$ \\
\hline Net Sale PP\&E & $\begin{array}{c}0.201 \\
(0.001)\end{array}$ & $\begin{array}{c}0.241 \\
(0.000)\end{array}$ & $\begin{array}{c}0.239 \\
(0.000)\end{array}$ & $\begin{array}{c}0.234 \\
(0.000)\end{array}$ & $\begin{array}{c}0.238 \\
(0.000)\end{array}$ & $\begin{array}{c}0.239 \\
(0.000)\end{array}$ & $\begin{array}{c}0.232 \\
(0.000)\end{array}$ & $\begin{array}{c}0.236 \\
(0.000)\end{array}$ \\
\hline Cash Flow & $\begin{array}{c}0.262 \\
(0.000)\end{array}$ & $\begin{array}{c}0.313 \\
(0.000)\end{array}$ & $\begin{array}{l}0.316 \\
(0.000)\end{array}$ & $\begin{array}{c}0.315 \\
(0.000)\end{array}$ & $\begin{array}{c}0.313 \\
(0.000)\end{array}$ & $\begin{array}{c}0.317 \\
(0.000)\end{array}$ & $\begin{array}{c}0.317 \\
(0.000)\end{array}$ & $\begin{array}{c}0.307 \\
(0.000)\end{array}$ \\
\hline Ln(Assets) & $\begin{array}{c}0.000 \\
(0.882)\end{array}$ & $\begin{array}{l}-0.000 \\
(0.716)\end{array}$ & $\begin{array}{l}-0.000 \\
(0.696)\end{array}$ & $\begin{array}{l}-0.000 \\
(0.828)\end{array}$ & $\begin{array}{l}-0.000 \\
(0.716)\end{array}$ & $\begin{array}{l}-0.000 \\
(0.680)\end{array}$ & $\begin{array}{l}-0.000 \\
(0.663)\end{array}$ & $\begin{array}{l}-0.000 \\
(0.750)\end{array}$ \\
\hline Change in NWC & $\begin{array}{l}- \\
-\end{array}$ & $\begin{array}{l}-0.254 \\
(0.000)\end{array}$ & $\begin{array}{l}-0.253 \\
(0.000)\end{array}$ & $\begin{array}{l}-0.225 \\
(0.000)\end{array}$ & $\begin{array}{l}-0.252 \\
(0.000)\end{array}$ & $\begin{array}{l}-0.253 \\
(0.000)\end{array}$ & $\begin{array}{l}-0.253 \\
(0.000)\end{array}$ & $\begin{array}{l}-0.252 \\
(0.000)\end{array}$ \\
\hline $\begin{array}{l}\text { Forced Turnover } \\
\text { Successor }\end{array}$ & $\begin{array}{l}- \\
-\end{array}$ & - & $\begin{array}{c}0.007 \\
(0.048)\end{array}$ & $\begin{array}{c}0.009 \\
(0.034)\end{array}$ & $\begin{array}{c}0.005 \\
(0.167)\end{array}$ & $\begin{array}{c}0.008 \\
(0.028)\end{array}$ & $\begin{array}{c}0.013 \\
(0.097)\end{array}$ & $\begin{array}{c}0.004 \\
(0.372)\end{array}$ \\
\hline For_succ * Chg_nwc & $\begin{array}{l}- \\
-\end{array}$ & $\begin{array}{l}- \\
-\end{array}$ & $\begin{array}{l}- \\
-\end{array}$ & $\begin{array}{l}-0.231 \\
(0.004)\end{array}$ & $\begin{array}{l}- \\
-\end{array}$ & $\begin{array}{l}- \\
-\end{array}$ & $\begin{array}{l}- \\
-\end{array}$ & $\begin{array}{l}- \\
-\end{array}$ \\
\hline For_succ * Net_issue & $\begin{array}{l}- \\
-\end{array}$ & $\begin{array}{l}- \\
-\end{array}$ & $\begin{array}{l}- \\
-\end{array}$ & - & $\begin{array}{l}-0.094 \\
(0.204)\end{array}$ & $\begin{array}{l}- \\
-\end{array}$ & $\begin{array}{l}- \\
-\end{array}$ & $\begin{array}{l}- \\
-\end{array}$ \\
\hline For_succ * Net_debt & $\begin{array}{l}- \\
-\end{array}$ & - & $\begin{array}{l}- \\
-\end{array}$ & $\begin{array}{l}- \\
-\end{array}$ & - & $\begin{array}{c}0.086 \\
(0.024)\end{array}$ & $\begin{array}{l}- \\
-\end{array}$ & $\begin{array}{l}- \\
-\end{array}$ \\
\hline For_succ $*$ Net_PP\&E & - & $\begin{array}{l}- \\
-\end{array}$ & $\begin{array}{l}- \\
-\end{array}$ & $\begin{array}{l}- \\
-\end{array}$ & $\begin{array}{l}- \\
-\end{array}$ & - & $\begin{array}{c}0.112 \\
(0.229)\end{array}$ & $\begin{array}{l}- \\
-\end{array}$ \\
\hline For_succ * Cashflow & - & - & - & - & - & - & $\begin{array}{l}- \\
-\end{array}$ & $\begin{array}{c}0.028 \\
(0.563)\end{array}$ \\
\hline $\begin{array}{l}\text { Observations } \\
\text { Adj. } R 2\end{array}$ & $\begin{array}{l}3,729 \\
0.216\end{array}$ & $\begin{array}{l}3,729 \\
0.288\end{array}$ & $\begin{array}{l}3,729 \\
0.290\end{array}$ & $\begin{array}{l}3,729 \\
0.292\end{array}$ & $\begin{array}{l}3,729 \\
0.290\end{array}$ & $\begin{array}{l}3,729 \\
0.291\end{array}$ & $\begin{array}{l}3,729 \\
0.290\end{array}$ & $\begin{array}{l}3,729 \\
0.290\end{array}$ \\
\hline
\end{tabular}




\section{Table VIII}

\section{Regressions on the Sources of Cash as Measured by the Components of NWC}

This table provides Fama-MacBeth regression results for changes in cash holdings on components of Net Working Capital. The dependent variable is the percentage change in cash holdings, measured by (cash $\mathrm{t}_{\mathrm{t}}$ $\left.\operatorname{cash}_{\mathrm{t}-1}\right) /\left(\right.$ assets $\left._{\mathrm{t}-1}\right)$. Panel A provides estimates on components of current assets (excluding cash). Forced_succ ${ }^{*} C h g$ CA, Forced_succ ${ }^{*} C h g$ AR, Forced_succ $*$ Chg_Inv, and Forced_succ*Chg_Othr_CA are interactions between Forced Turnover Successor and Change in CA, Change in AR, Change in Inventory, and Change in CA(Other), respectively. Panel B provides estimates on components of current liabilities. Forced_succ*Chg_CL, Forced_succ*Chg_AP, Forced_succ*Chg_Stdebt, and Forced_succ *Chg_Othr_CL are interactions between Forced Turnover Successor and Change in CL, Change in AP, Change in ST Debt, and Change in CL(Other), respectively. Definitions of all other independent variables are provided in the appendix. The year of the turnover $(\mathrm{t}=0)$ is excluded from the sample since it represents a transition period for executives and it is unclear whether predecessor or successor policy is implemented at this time. All variables are winsorized at the $1 \%$ and $99 \%$ levels.

\begin{tabular}{|c|c|c|c|c|c|c|}
\hline \multicolumn{7}{|c|}{ Panel A: Current Assets (excluding cash) } \\
\hline Independent Variable & Model 1 & Model 2 & Model 3 & Model 4 & Model 5 & Model 6 \\
\hline \multirow[t]{2}{*}{ Constant } & 0.001 & -0.000 & -0.010 & -0.011 & -0.012 & -0.010 \\
\hline & $(0.880)$ & $(0.996)$ & $(0.401)$ & $(0.340)$ & $(0.325)$ & $(0.428)$ \\
\hline \multirow[t]{2}{*}{ Net Issue } & 0.456 & 0.456 & 0.470 & 0.470 & 0.469 & 0.470 \\
\hline & $(0.000)$ & $(0.000)$ & $(0.000)$ & $(0.000)$ & $(0.000)$ & $(0.000)$ \\
\hline \multirow[t]{2}{*}{ Net Debt } & 0.162 & 0.160 & 0.171 & 0.168 & 0.170 & 0.171 \\
\hline & $(0.000)$ & $(0.000)$ & $(0.000)$ & $(0.000)$ & $(0.000)$ & $(0.000)$ \\
\hline \multirow[t]{2}{*}{ Net Sale PP\&E } & 0.204 & 0.202 & 0.206 & 0.205 & 0.203 & 0.208 \\
\hline & $(0.001)$ & $(0.001)$ & $(0.001)$ & $(0.001)$ & $(0.001)$ & $(0.001)$ \\
\hline \multirow[t]{2}{*}{ Cash Flow } & 0.317 & 0.316 & 0.350 & 0.350 & 0.349 & 0.350 \\
\hline & $(0.000)$ & $(0.000)$ & $(0.000)$ & $(0.000)$ & $(0.000)$ & $(0.000)$ \\
\hline \multirow{2}{*}{ Ln(Assets) } & 0.000 & 0.000 & 0.001 & 0.001 & 0.001 & 0.001 \\
\hline & $(0.984)$ & $(0.854)$ & $(0.322)$ & $(0.269)$ & $(0.256)$ & $(0.345)$ \\
\hline \multirow[t]{2}{*}{ Forced Turnover Successor } & 0.006 & 0.008 & 0.005 & 0.006 & 0.007 & 0.005 \\
\hline & $(0.076)$ & $(0.037)$ & $(0.124)$ & $(0.119)$ & $(0.066)$ & $(0.121)$ \\
\hline \multirow[t]{2}{*}{ Change in CA } & -0.153 & -0.141 & - & - & - & - \\
\hline & $(0.008)$ & $(0.010)$ & - & - & - & - \\
\hline \multirow[t]{2}{*}{ Forced_succ $*$ Chg_CA } & - & -0.086 & - & - & - & - \\
\hline & - & $(0.170)$ & - & - & - & - \\
\hline \multirow[t]{2}{*}{ Change in AR } & - & - & -0.149 & -0.130 & -0.144 & -0.143 \\
\hline & - & - & $(0.041)$ & $(0.057)$ & $(0.050)$ & $(0.044)$ \\
\hline \multirow[t]{2}{*}{ Change in Inventory } & - & - & -0.316 & -0.310 & -0.286 & -0.321 \\
\hline & - & - & $(0.000)$ & $(0.000)$ & $(0.000)$ & $(0.000)$ \\
\hline \multirow[t]{2}{*}{ Change in Other CA } & - & - & 0.149 & 0.147 & 0.140 & 0.136 \\
\hline & - & - & $(0.336)$ & $(0.345)$ & $(0.372)$ & $(0.379)$ \\
\hline \multirow[t]{2}{*}{ Forced_succ $*$ Chg_AR } & - & - & - & -0.212 & - & - \\
\hline & - & - & - & $(0.134)$ & - & - \\
\hline \multirow[t]{2}{*}{ For_succ $*$ Chg_Inv } & - & - & - & - & -0.237 & - \\
\hline & - & - & - & - & $(0.088)$ & - \\
\hline \multirow[t]{2}{*}{ For_succ * Chg_Othr_CA } & - & - & - & - & - & 0.104 \\
\hline & - & - & - & - & - & $(0.591)$ \\
\hline Observations & 3,729 & 3,729 & 3,687 & 3,687 & 3,687 & 3,687 \\
\hline Adj. $R 2$ & 0.242 & 0.242 & 0.246 & 0.248 & 0.246 & 0.246 \\
\hline
\end{tabular}


Table VIII continued

\begin{tabular}{|c|c|c|c|c|c|c|}
\hline \multicolumn{7}{|l|}{ Panel B: Current Liabilities } \\
\hline Independent Variable & Model 1 & Model 2 & Model 3 & Model 4 & Model 5 & Model 6 \\
\hline \multirow[t]{2}{*}{ Constant } & 0.002 & 0.002 & -0.001 & -0.001 & -0.001 & -0.002 \\
\hline & $(0.844)$ & $(0.791)$ & $(0.903)$ & $(0.940)$ & $(0.945)$ & $(0.854)$ \\
\hline \multirow[t]{2}{*}{ Net Issue } & 0.397 & 0.398 & 0.404 & 0.406 & 0.402 & 0.402 \\
\hline & $(0.000)$ & $(0.000)$ & $(0.000)$ & $(0.000)$ & $(0.000)$ & $(0.000)$ \\
\hline \multirow[t]{2}{*}{ Net Debt } & 0.108 & 0.109 & 0.117 & 0.119 & 0.117 & 0.119 \\
\hline & $(0.002)$ & $(0.001)$ & $(0.001)$ & $(0.001)$ & $(0.001)$ & $(0.001)$ \\
\hline \multirow[t]{2}{*}{ Net Sale PP\&E } & 0.220 & 0.214 & 0.203 & 0.201 & 0.206 & 0.208 \\
\hline & $(0.000)$ & $(0.000)$ & $(0.001)$ & $(0.001)$ & $(0.001)$ & $(0.001)$ \\
\hline \multirow[t]{2}{*}{ Cash Flow } & 0.262 & 0.261 & 0.275 & 0.275 & 0.277 & 0.269 \\
\hline & $(0.000)$ & $(0.000)$ & $(0.000)$ & $(0.000)$ & $(0.000)$ & $(0.000)$ \\
\hline \multirow[t]{2}{*}{ Ln(Assets) } & 0.000 & 0.000 & 0.000 & 0.000 & 0.000 & 0.000 \\
\hline & $(0.883)$ & $(0.950)$ & $(0.733)$ & $(0.756)$ & $(0.811)$ & $(0.599)$ \\
\hline \multirow[t]{2}{*}{ Forced Turnover Successor } & 0.008 & 0.008 & 0.008 & 0.008 & 0.010 & 0.007 \\
\hline & $(0.038)$ & $(0.053)$ & $(0.033)$ & $(0.062)$ & $(0.022)$ & $(0.059)$ \\
\hline \multirow[t]{2}{*}{ Change in CL } & 0.074 & 0.067 & - & - & - & - \\
\hline & $(0.017)$ & $(0.026)$ & - & - & - & - \\
\hline \multirow[t]{2}{*}{ Forced_succ * Chg_CL } & - & 0.062 & - & - & - & - \\
\hline & - & $(0.306)$ & - & - & - & - \\
\hline \multirow[t]{2}{*}{ Change in AP } & - & - & -0.156 & -0.214 & -0.155 & -0.160 \\
\hline & - & - & $(0.139)$ & $(0.052)$ & $(0.137)$ & $(0.103)$ \\
\hline \multirow[t]{2}{*}{ Change in ST Debt } & - & - & 0.001 & 0.002 & -0.017 & 0.000 \\
\hline & - & - & $(0.972)$ & $(0.949)$ & $(0.516)$ & $(0.997)$ \\
\hline \multirow[t]{2}{*}{ Change in Other CL } & - & - & 0.201 & 0.217 & 0.205 & 0.184 \\
\hline & - & - & $(0.001)$ & $(0.001)$ & $(0.001)$ & $(0.011)$ \\
\hline \multirow[t]{2}{*}{ Forced_succ $*$ Chg_AP } & - & - & - & 0.070 & - & - \\
\hline & - & - & - & $(0.650)$ & - & - \\
\hline \multirow[t]{2}{*}{ Forced_succ $*$ Chg_Stdebt } & - & - & - & - & 0.160 & - \\
\hline & - & - & - & - & $(0.077)$ & - \\
\hline \multirow[t]{2}{*}{ Forced_succ * Chg_Othr_CL } & - & - & - & - & - & -0.102 \\
\hline & - & - & - & - & - & $(0.510)$ \\
\hline Observations & 3,729 & 3,729 & 3,729 & 3,729 & 3,729 & 3,729 \\
\hline Adj. $R 2$ & 0.225 & 0.226 & 0.239 & 0.240 & 0.242 & 0.240 \\
\hline
\end{tabular}




\section{Table IX}

The Effect of Turnover and Successor Characteristics on the Value of Cash Holdings

This table provides OLS regression estimates measuring the value of cash. The dependent variable is the excess stock return of the firm, defined as the annual fiscal year stock return minus the matched Fama French $5 \times 5$ portfolio return. The delta $(\Delta)$ refers to the change in the variable of interest over the period t1 to t. Forced turnover successor and outside industry successor is defined in Table III. Definitions of all other independent variables are provided in the Appendix. The year of the turnover $(t=0)$ is excluded from the sample since it represents a transition period for executives and it is unclear whether predecessor or successor policy is implemented during this time. Definitions of all independent variables are provided in the Appendix. p-values based on standard errors clustered at the firm level are provided in parentheses. All variables are winsorized at the $1 \%$ and $99 \%$ levels.

\begin{tabular}{|c|c|c|c|}
\hline Independent Variable & Model 1 & Model 2 & Model 3 \\
\hline \multirow[t]{2}{*}{ Intercept } & 0.041 & 0.040 & 0.045 \\
\hline & $(0.000)$ & $(0.000)$ & $(0.000)$ \\
\hline \multirow[t]{2}{*}{$\Delta$ Cash $_{\mathrm{t}}$} & 0.836 & 0.820 & 0.783 \\
\hline & $(0.000)$ & $(0.000)$ & $(0.000)$ \\
\hline \multirow[t]{2}{*}{$\Delta$ Earnings $_{\mathrm{t}}$} & 0.354 & 0.353 & 0.350 \\
\hline & $(0.000)$ & $(0.000)$ & $(0.000)$ \\
\hline \multirow[t]{2}{*}{$\Delta$ Net Assets $_{t}$} & 0.125 & 0.126 & 0.124 \\
\hline & $(0.000)$ & $(0.000)$ & $(0.000)$ \\
\hline \multirow[t]{2}{*}{$\Delta \mathrm{R} \& \mathrm{D}_{\mathrm{t}}$} & 0.389 & 0.408 & 0.405 \\
\hline & $(0.610)$ & $(0.589)$ & $(0.580)$ \\
\hline \multirow[t]{2}{*}{$\Delta$ Interest Expense $_{t}$} & -1.085 & -1.077 & -1.013 \\
\hline & $(0.124)$ & $(0.125)$ & $(0.149)$ \\
\hline \multirow[t]{2}{*}{$\Delta$ Dividends $_{\mathrm{t}}$} & -1.606 & -1.575 & -1.630 \\
\hline & $(0.104)$ & $(0.109)$ & $(0.096)$ \\
\hline \multirow[t]{2}{*}{ Cash $_{\mathrm{t}-1}$} & 0.242 & 0.234 & 0.231 \\
\hline & $(0.000)$ & $(0.000)$ & $(0.000)$ \\
\hline \multirow[t]{2}{*}{ Leverage $_{t}$} & -0.311 & -0.312 & -0.319 \\
\hline & $(0.000)$ & $(0.000)$ & $(0.000)$ \\
\hline \multirow[t]{2}{*}{ Net Financing ${ }_{t}$} & -0.171 & -0.169 & -0.167 \\
\hline & $(0.006)$ & $(0.007)$ & $(0.007)$ \\
\hline \multirow[t]{2}{*}{$\operatorname{Cash}_{\mathrm{t}-1} * \Delta \operatorname{Cash}_{\mathrm{t}}$} & -0.498 & -0.513 & -0.516 \\
\hline & $(0.204)$ & $(0.186)$ & $(0.174)$ \\
\hline \multirow[t]{2}{*}{ Leverage $_{t} * \Delta$ Cash $_{t}$} & -0.562 & -0.551 & -0.485 \\
\hline & $(0.171)$ & $(0.178)$ & $(0.237)$ \\
\hline \multirow[t]{2}{*}{ Forced Turnover Successor } & - & 0.023 & 0.040 \\
\hline & - & $(0.385)$ & $(0.125)$ \\
\hline \multirow[t]{2}{*}{ Forced_succ $* \Delta$ Cash $_{\mathrm{t}}$} & - & 0.062 & - \\
\hline & - & $(0.769)$ & - \\
\hline \multirow[t]{2}{*}{ Outside Industry Successor } & - & - & -0.055 \\
\hline & - & - & $(0.038)$ \\
\hline \multirow{2}{*}{$\begin{array}{l}\text { Forced Turnover Outside } \\
\text { Industry Successor }\end{array}$} & - & - & -0.057 \\
\hline & - & - & $(0.414)$ \\
\hline \multirow[t]{2}{*}{ Forced_outind* $\Delta$ Cash $_{\mathrm{t}}$} & - & - & 0.622 \\
\hline & - & - & $(0.144)$ \\
\hline Number of observations & 3,387 & 3,387 & 3,387 \\
\hline Adj. $R 2$ & 0.2355 & 0.2363 & 0.2347 \\
\hline
\end{tabular}


Figure 1

Difference between Forced and Voluntary Cash Holdings Relative to Turnover Year

This figure provides the percentage difference in cash holdings between CEOs surrounding forced turnovers relative to voluntary turnovers. Specifically, the plotted annual coefficient differences represent estimates of the difference between cash holdings of predecessors (successors) surrounding forced turnovers compared to cash holdings of predecessors (successors) surrounding voluntary turnovers. Annual estimates of the coefficient differences are reported in Panel A of Table V.

Panel A: Controlling for firm and year effects

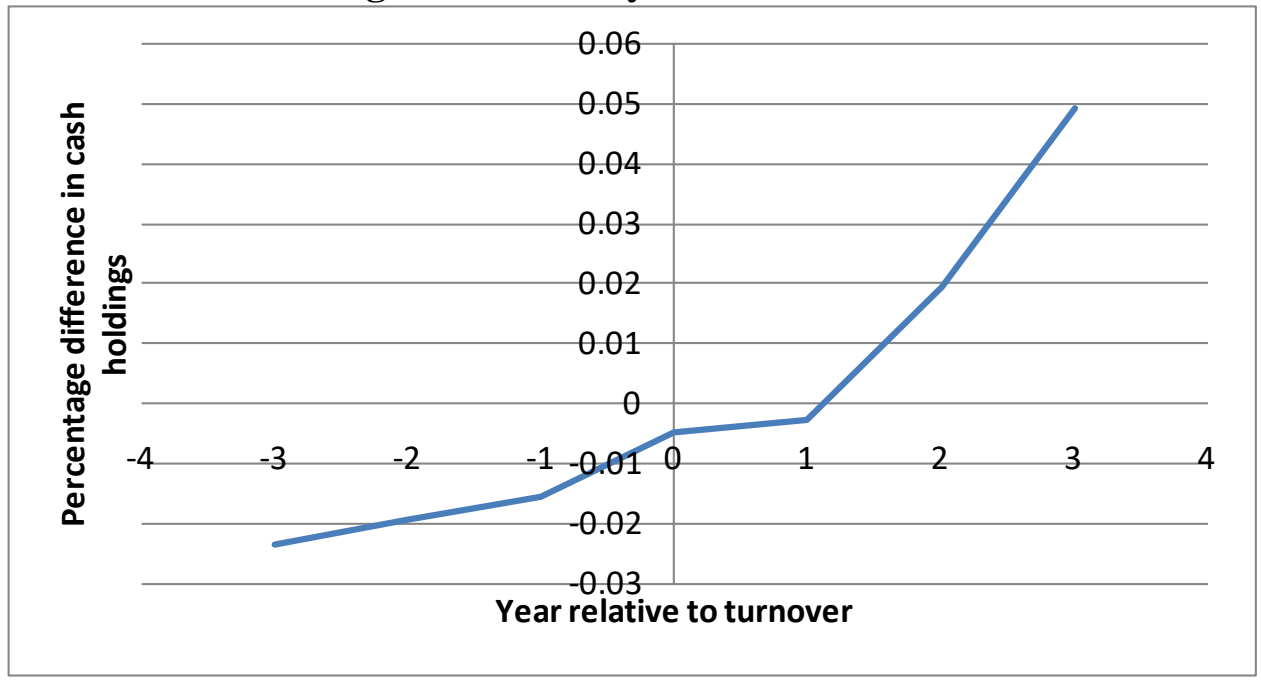

Panel B: Controlling for determinants of cash, firm and year effects

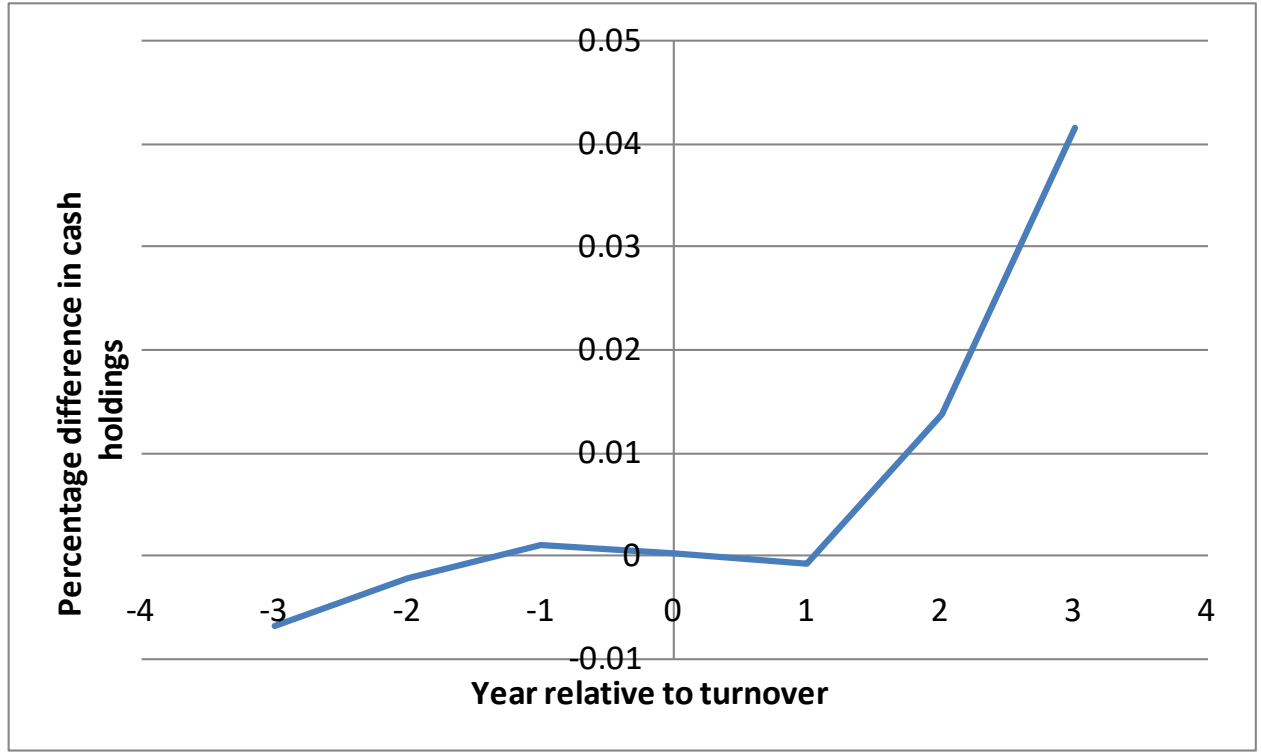


Panel C: Controlling for determinants of cash, governance, firm and year fixed effects

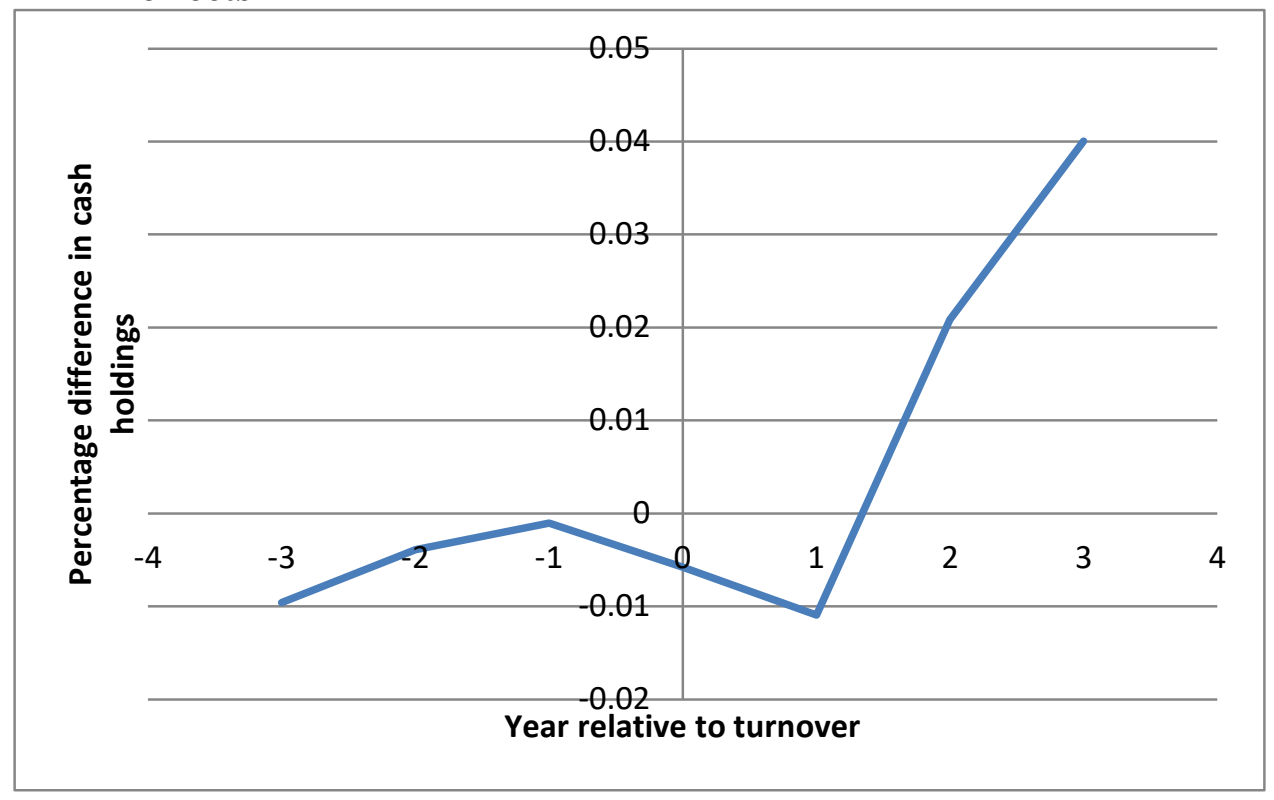


Appendix: Variable Definitions

\begin{tabular}{|c|c|}
\hline Variable Name & Definition \\
\hline Cash / Assets & Cash (che) / assets (at) \\
\hline Firm Size & Inflation adjusted book assets (at) \\
\hline Leverage & [Long-term debt $(d l t t)+$ short-term debt $(d l c)] /$ assets $(a t)$ \\
\hline Market to Book & [Book assets $(a t)-$ book equity $(c e q)+$ market equity $\left.\left(p r c c \_c{ }^{*} c s h o\right)\right] /$ book assets $(a t)$ \\
\hline Cash Flow / Assets & [OIBD (oibdp) - interest (xint) - income taxes $(t x t)$ - dividends $(d v c)]$ / assets $(a t)$ \\
\hline Net Working Capital / Assets & [Working capital (wcap) - cash (che)] / assets (at) \\
\hline Cash Flow Volatility & The mean standard deviation of cash flow/assets over the previous 5 years \\
\hline R\&D / Sales & $\mathrm{R} \& \mathrm{D}(x r d) /$ sales (sale) \\
\hline CAPEX / Assets & Capital expenditures(capx) / assets (at) \\
\hline Acquisitions / Assets & Acquisitions $(a q c) /$ assets (at) \\
\hline Writeoffs / Assets & Special items (spi ) / assets (at) or zero when missing or positive \\
\hline Dividends & Dummy variable set equal to 1 if dividends $(d v c)>0$ \\
\hline Board Size & Lagged board size \\
\hline Board Independence & Lagged ratio of outside directors to total directors \\
\hline CEO Duality & Dummy variable set equal to 1 if CEO also holds the post of Chairman \\
\hline Founding Family CEO & Dummy variable set equal to 1 if CEO is a founder, co-founder, or relative of the firm founder(s) \\
\hline Blockholder Ownership & Lagged percentage ownership of holders that own at least 5\% of the firm \\
\hline$\Delta$ Cash $_{\mathrm{t}}$ & [Cash (che ) - lagged cash] / [lagged market value of equity (cshpri* prcc_f)] \\
\hline$\Delta$ Earnings $_{\mathrm{t}}$ & [Earnings $(i b+x i n t+t x d i+i t c i)$ - lagged earnings] / [lagged market value of equity] \\
\hline$\Delta$ Net Assets $_{t}$ & [Net assets (at - che ) - lagged net assets] / [lagged market value of equity] \\
\hline$\Delta \mathrm{R} \& \mathrm{D}_{\mathrm{t}}$ & [R\&D (xrd) - lagged R\&D] / [lagged market value of equity] \\
\hline$\Delta$ Interest Expense ${ }_{t}$ & [Interest expense (xint) - lagged interest expense] / [lagged market value of equity] \\
\hline$\Delta$ Dividends $_{\mathrm{t}}$ & [Dividends $(d v c)$ - lagged dividends] / [lagged market value of equity] \\
\hline Cash $_{\mathrm{t}-1}$ & [lagged cash] / [lagged market value of equity] \\
\hline Leverage $_{t}$ & {$[(d l t t+d l c)] /\left[\left(d l t t+d l c+c s p r i * p r c c \_f\right)\right]$} \\
\hline Net Financing & {$[$ sstk - prstkc + dltis - dltr $]$} \\
\hline
\end{tabular}




\section{Appendix (Continued)}

\begin{tabular}{|c|c|}
\hline Variable Name & Definition \\
\hline Net Issue & $\begin{array}{l}\text { [Sale of common and preferred stock (sstk) - Purchase of common and preferred stock (prstkc) - Cash } \\
\text { dividends }(d v)] \text { / lagged assets (lagged at) }\end{array}$ \\
\hline Net Debt & [Long-term debt issuance (dltis ) - Long-term debt reduction (dltr )] / lagged assets \\
\hline Net Sale PP\&E & [Sale of property, plant \& equipment (sppe) - Capital expenditures (capx)] / lagged assets \\
\hline Cash Flow & [Net Income $(n i)+$ Depreciation and Amortization $(d p)]$ / lagged assets \\
\hline Change in NWC & $\{[$ Working capital (wcap) - cash (che )] - [lagged working capital - lagged cash]\} / lagged assets \\
\hline Change in CA & $\{[$ Current assets $(a c t)$ - cash (che $)]$ - [lagged current assets - lagged cash]\} / lagged assets \\
\hline Change in AR & [Accounts receivable (rect) - lagged accounts receivable] / lagged assets \\
\hline Change in Inventory & [Inventories (invt) - lagged inventories] / lagged assets \\
\hline Change in CA (Other) & [Current assets, other ( $a c o$ ) - lagged current assets, other] / lagged assets \\
\hline Change in CL & [Current liabilities (lct) - lagged current liabilities] / lagged assets \\
\hline Change in ST Debt & [Debt in current liabilities ( $d l c$ ) - lagged debt in current liabilities] / lagged assets \\
\hline Change in CL (Other) & [Current liabilities, other (ppenc) - lagged current liabilities, other] / lagged assets \\
\hline
\end{tabular}

